\title{
Smectite, illite, and early diagenesis in South Pacific Gyre subseafloor
}

\section{sediment}

Kiho Yang ${ }^{\mathrm{a}}$, Jin-wook Kim ${ }^{\mathrm{a},}$, Toshihiro Kogure ${ }^{\mathrm{b}}$, Hailiang Dong ${ }^{\mathrm{c}}$, Hionsuck Baik ${ }^{\mathrm{d}}$, Bryce Hoppie $^{\mathrm{e}}$, and Robert Harris ${ }^{\mathrm{f}}$

${ }^{\mathrm{a}}$ Department of Earth System Sciences, Yonsei University, Sinchon-dong, Seodaemun-gu, Seoul 120-749, Korea

${ }^{b}$ Department of Earth and Planetary Sciences, Graduate School of Science, The University of Tokyo 7-3-1 Hongo, Bunkyo-ku, Tokyo 113-0033, Japan

${ }^{c}$ Department of Geology and Environmental Earth Science, Miami University, Oxford, OH 45056, USA

${ }^{\mathrm{d} D i v i s i o n}$ of Analytical Research, Korea Basic Science Institute (KBSI), 74 Inchon-ro, Sungbuk-gu, Seoul 136-713, Korea

${ }^{\mathrm{e}}$ Department of Chemistry and Geology, Minnesota State University, Mankato, MN 56001, USA

${ }^{\mathrm{f}}$ College of Earth, Ocean, and Atmospheric Sciences, Oregon State University, Corvallis, OR 97331, USA

*Corresponding author: Department of Earth System Sciences, Yonsei University, Seoul, Korea. Tel.: +82 22123 5668; fax: +82 22123 8169; jinwook@yonsei.ac.kr 


\section{Abstract}

Subseafloor sediment and basalt rock samples at seven sites in the South Pacific Gyre (SPG) were recovered by Integrated Ocean Drilling Program Expedition 329 (2010.10.8 2010.12.13). Microscopic and spectroscopic measurements on the structural Fe-redox states and the elemental composition of smectite, and polytypes of illite in the sediment at two sites (U1365 and U1369) were performed to understand the origin/formation mechanism of clay minerals in the oligotrophic open ocean. The dominant phases of clay minerals found in the present study were smectite and illite polytypes. Suggestive of non-uniform early diagenetic processes in the expansive SPG seafloor, higher ordering of illite polytypes $\left(1 M, 2 M_{1}\right.$, and $\left.3 T\right)$ were identified at site U1369 while disordered $1 M_{d}$ illite were found at U1365. Smectites of hydrothermal origin (Al-rich beidellite, and saponite) were observed at U1369. Fe-rich montmorillonite minerals that are likely associated with the terrigenous input, were dominant at U1365. Nontronite (Fe-rich smectite) was detected at both sites. Red-brown to yellowbrown semiopaque oxide minerals (RSO) were widely distributed with Fe-rich smectite near the basaltic crust at U1365. Lower observed heat flow at U1365 relative to U1369 provides a possible explanation for the observed variability in clay mineral speciation between these two sites. The presence of K-nontronite at the basalt/sediment interface at both sites indicates an oxidative basalt alteration; however variations in the oxidation states of structural $\mathrm{Fe}$ in nontronite measured by EELS indicate that reductive environment persists locally at the basalt/sediment interface.

Keywords: South Pacific Gyre; K-nontronite; diagenesis; Illite polytypism; IODP Expedition 


\section{Introduction}

Integrated Ocean Drilling Program (IODP) Expedition 329 recovered subseafloor sediment and basalt rock samples across a range of crustal ages and tectonic spreading rates in the South Pacific Gyre (SPG). The SPG is a unique depositional environment where the sedimentation rates are among the lowest (less than 1.6 to $1.9 \mathrm{~m} / \mathrm{Myr}$ ) of any seafloor setting on Earth, and sediments and basaltic basement have been continuously exposed to oxic conditions for their entire sedimentation history (D'Hondt et al., 2009, 2015). The low sedimentation rates are due to extremely low influxes of terrigenous matters and low bioproduction in the euphotic zone (Anderson, 1986; Glasby, 1991; Claustre and Maritorena, 2003; D’Hondt et al., 2009). Given these unique conditions, the formation of subseafloor sediments, particularly the composition and structure of clay minerals and their formation mechanism supposed to be different from those in the anoxic conditions of equatorial upwelling regions and high accumulation rates at the continental margins (D'Hondt et al., 2015). IODP Expedition 329, for the first time, allows investigation of a vast range of mineralogical data throughout the entire sedimentary column of the SPG.

Smectites in subseafloor sediment can originate from aerial or fluvial influx of terrigenous material, or hydrothermal alteration of basalt (Biscaye, 1965; Chamley, 1989; Weaver, 1989; Fagel et al., 2001). Variations of chemistry and crystalline structure within smectites reflect their origin and formation mechanisms (Wilson, 1999). Trioctahedral smectite, mainly occurring as the mineral saponite, likely forms through the hydrothermal alteration of basaltic basement igneous rocks (Zierenberg et al., 1983; Cole, 1988; Cuadros et al., 2008, 2013; Dekov et al., 2008). Dioctahedral Al-rich smectite (beidellite) appears to form via interactions among hydrothermal solutions and sediment at high temperatures $(\sim 160$ 
to $200^{\circ} \mathrm{C}$ ) (Haggerty and Baker, 1967; McMurthy et al., 1983; Parra et al., 1985, 1986; Fagel et al., 2001). Fe-rich smectite, known as the mineral nontronite, is quite frequent in hydrothermally altered basalt (Zierenberg et al., 1983; Cuadros et al., 2008, 2013; Dekov et al., 2008), although Pacific pelagic clays also possess nontronite that possibly forms through low temperature reactions within subseafloor sediment (Cuadros et al., 2011).

Fe-rich smectite, particularly nontronite has variable crystal structure and chemistry. Variation of $\mathrm{Fe}(\mathrm{II}) / \mathrm{Fe}(\mathrm{III})$ in smectite structure is likely attributable to redox changes that may involve oxidation of organic matter (Eslinger et al., 1979), or local microbial Ferespiration (Gates et al., 1998; Kostka et al., 1996, 1999a,b; Stucki, 1998; Kim et al., 2003, 2004; Zhang et al., 2007a,b; Jaisi et al., 2005, 2007a,b, 2011; Seabaugh et al., 2006; Stucki and Kostka, 2006; Dong et al., 2009). In contrast, the formation of K-smectite indicates an oxidative weathering process of subseafloor sediment in the presence of seawater (Hart et al., 1974; Clayton et al., 2000; Zhou et al., 2001). Variations in mica polytypes associated with endogenous heat flow (Nespolo et al., 2001) are common in sediments. In subseafloor hydrothermal deposits, micas develop the stacking order with a sequence of $1 M_{\mathrm{d}}-1 M-2 M_{1}$ depending on the hydrothermal activity and reaction time (Yoder, 1959; Velde, 1965). The structural assessments by Selected Area Electron Diffraction (SAED) pattern allows to detect the evolution of mica polytypes in hydrothermal regions (Inoue et al., 1988; DiMarco et al., 1989). Pelagic red clays in the Pacific Ocean constitute $49 \%$ of seafloor sediment (Anderson, 1986). They are especially abundant in the southwestern Pacific Basin (Piper et al., 1985). Fe-rich smectite and Fe/Mn-oxyhydroxides are the dominant mineral phases in Pacific pelagic clays (Singer et al., 1984; Cuadros et al., 2011).

This study aims to investigate the structure and mineral composition of smectite phases and illite polytypes in the subseafloor sedimentary sequence in the oligotrophic open 
ocean of the SPG. Specific objectives of this research include (1) investigating the diversity of smectite phases, (2) determining the redox states of structural $\mathrm{Fe}$ in Fe-rich smectite, and (3) defining the elemental composition and formation mechanisms of clay minerals and polytypes of illite in the sediment of two oligotrophic sites (IODP Expedition 329 sites U1365 and U1369) that experienced long-term, low rates of sediment accumulation and persistent oxic conditions. Therefore, the present study provides insight into the processes of mineral formation and early diagenesis.

\section{Samples and methods}

\subsection{Sampling locations}

IODP Expedition 329 recovered subseafloor sediment from seven sampling sites along two transects spanning the western half of the SPG. One transect (sites U1365 - U1368) crosses the center of the SPG at $26^{\circ} \mathrm{S}$ from the upper slope of the East Pacific Rise (EPR) to the western abyssal plain with increasing basement age from $13.5 \mathrm{Ma}$ to $84-120 \mathrm{Ma}$ (Gradstein et al., 2004) (Fig. 1, Table 1). The entire sediment column at four sites and the upper $100 \mathrm{~m}$ of basement at three sites were cored along this transect. Water depths at these sites varied from 3740 meters below sea level (mbsl) to 5695 mbsl (Table 1). The other transect (sites U1369 - U1371) crosses the southern edge of the gyre at approximately $42^{\circ} \mathrm{S}$ and also sampled the entire sediment column at each site. Crustal ages is $75 \mathrm{Ma}$ and water depths increase from $5075 \mathrm{~m}$ to $5305 \mathrm{~m}$. Sediment cores were recovered at three sites where basement rocks were deliberately not cored. The thickness of the sediment column in the 
SPG seafloor increases with the basement age and is greatest at site U1371 (131 m), a location that is influenced by upwelling along the southwestern edge of the SPG (D'Hondt et al., 2009). Expedition 329 shipboard scientists characterized the overall stratigraphy and preliminary mineralogy for all recovered cores (Expedition 329 Scientists, 2011). Based on those results and to more fully characterize differences among the sites with respect to crustal age and position within the SPG, sites U1365 and U1369 were selected for further study. Sites U1367 and U1368 were excluded from further consideration because the dominant lithology at those sites is calcareous nannofossil ooze; site U1371 was excluded because its cores are composed primarily of siliceous ooze. Site U1365 is located $4500 \mathrm{~km}$ west of the EPR. It represents the location furthest from the ridge and resides on the oldest crust available within the SPG, dated at 124.6 Ma (Gradstein et al., 2004). Sediment recovered at site U1369 resides upon crust dated at $58 \mathrm{Ma}$, approximately $2000 \mathrm{~km}$ west of the EPR.

\subsection{Clay mineral separation}

Samples from various depths were sub-cored from split cores at two sites (U1365 and U1369) based on the core description. A total of 16 and 10 clay samples were prepared from sites U1365 and U1369, respectively. In brief, sample preparation included: (1) chemical treatment with sodium acetate $(\mathrm{NaOAc})$ - acetic acid (HOAc) buffer solution (pH 5.0) and hydrogen peroxide $\left(30 \% \mathrm{H}_{2} \mathrm{O}_{2}\right)$ to remove carbonate and organic matter (Jackson, 1969); (2) multiple washes with distilled water to remove any residues of the chemical reagents; (3) separation of the clay-size fraction ( $<1 \mu \mathrm{m})$ by centrifuge (Jackson, 1969); (4) reduction of clay dispersion volume by addition of sodium chloride $(\mathrm{NaCl}) ;(5)$ removal of excess salt by dialysis; and (6) final dried clay sample acquisition by freeze-drying (Malcolm, 
1968).

\section{3. $X$-ray diffraction (XRD) and optical microscopy}

XRD analyses were performed on air-dried and glycolated samples using a Rigaku Mini-Flex II automated X-ray diffractometer with $\mathrm{Cu}-\mathrm{K} \alpha$ radiation at Yonsei University. Fine clay samples were dispersed in distilled water $(0.5 \mathrm{mg} / \mathrm{ml})$ and immersed in an ultrasonic water bath to minimize any flocculation induced by freeze-drying. Oriented powder mount samples were prepared by pipetting sediment dispersions onto glass slides and gently taping the bottom of the slide to coax the clay particles into settling on their $a$ - $b$ crystallographic plane. XRD profiles over ranges of $2 \theta$ degrees from $3^{\circ}$ to $40^{\circ}$ (air-dried), and $3^{\circ}$ to $15^{\circ}$ (glycolated) were recorded at scan speeds of $1.5^{\circ} / \mathrm{min}$ and step sizes of $0.02^{\circ}$ with a receiving slit size of $0.3 \mathrm{~mm}$ and a divergence slit size of $1.25^{\circ}$. Crystallographica Search-Match software (version 2.0.3.1) was used to identify the composition of minerals constituting each clay sample. The smear slides for various depths were examined to estimate the mineral composition at $\mathrm{x} 50-\mathrm{x} 100$ magnifications under the optical polarization microscopy. The semi-quantification of mineral contents was measured based on the visual percentage estimation using the comparator chart (Marsaglia et al., 2013).

\subsection{Transmission electron microscopy (TEM)}

A JEOL JEM-2010 UHR TEM equipped with EDS (JEOL JED-2200) at the University of Tokyo was operated at $200 \mathrm{kV}$ to examine structural and chemical variations of clay minerals on lattice fringe images, Selected Area Electron Diffraction (SAED) patterns, 
and Energy Dispersive X-ray Spectrometer (EDS) analyses. TEM samples were impregnated with L.R. White resin (Kim et al., 1995) to prevent structural artifacts caused by the dehydration of clay minerals under a vacuum in TEM. The cured samples were sliced to 70 $\mathrm{nm}$ in thickness using an ultramicrotome (ULTRACUT TCT; Leica, installed at the Korea Basic Science Institute, KBSI) and then placed on a holey carbon TEM Cu-grid. The lattice fringe images were used to differentiate the smectite layers (12-13 $)$ from the illite layers (10 A) while the EDS analyses were used to determine each mineral's elemental composition. The chemical composition of clay minerals were measured by Analytical Transmission Electron Microscopy (ATEM) with an acquisition time of 30 seconds under the bright-filed imaging mode. Background signals of EDS spectra (emsa file format) were removed by PeakFit - EDS S/W (Kogure, the University of Tokyo, 2012) and fitted by the least square method (LSM). The mass percent of elemental components (K, Na, Ca, Si, Al, Fe, Mg, Ti, and $\mathrm{Mn}$ ) were then calculated based on the relative peak intensity. The chemical formulas of the various clay minerals were determined by assuming that each unit cell contained 22oxygen atoms.

\subsection{Electron Energy Loss Spectroscopy (EELS)}

Electron Energy Loss Spectroscopy (EELS) was performed at the KBSI using a TECNAI G ${ }^{2}$ F30 ST FE-TEM (FEI Company, Hillsboro, Oregon, USA) equipped with a Gatan imaging filter operated at $300 \mathrm{kV}$. The operational conditions for EELS acquisition included an entrance aperture of $2.0 \mathrm{~mm}$, energy dispersion of $0.1 \mathrm{eV} / \mathrm{channel}$, and full width at half-maximum (FWHM) to $1.0 \mathrm{eV}$ for the zero-loss peak calibration. Fe $L$-edge spectra was acquired with an acquisition time of $5.0 \mathrm{~s}$ in the Scanning Transmission Electron 
Microscope (STEM) mode.

Standard procedures were used to measure the Fe-oxidation state of clay preparations

selected for EELS. The statistical optimum signal-window parameters for the integral ratio of Fe- $L_{2} / L_{3}$ edges were calculated using Gatan Digital Micrograph software. In particular, the background intensities were removed from EELS spectra through an application of standard power-law and double arctan functions. A window $\delta(30 \mathrm{eV})$ was selected in the background to extrapolate the curve over the post-edge window and the electron intensity under the extrapolated line was subtracted from a total intensity. Because the fit of the curve to the tail of a preceding edge shows similar power-law dependencies to the background (Williams and Carter, 2009), a double arctan function (Equation 1) was used as the background-function.

\section{Equation 1}

$$
f(\Delta E)=\frac{h 1}{\pi} \cdot\left[\arctan \left(\frac{\pi}{w 1} \cdot(\Delta E-E 1)+\frac{\pi}{2}\right)\right] \times\left[\frac{h 2}{\pi}\right] \times\left[\arctan \left(\frac{\pi}{w 2}\right) \cdot(\Delta E-E 2)+\frac{\pi}{2}\right]
$$

Two arctan functions (h1 and h2) associated with height (after the power-law was used to eliminate background effects) were then applied to the Fe $L_{3}$ and the Fe $L_{2}$ edges with fixed inflection points at $\mathrm{E} 1=710.0 \mathrm{eV}$ and $\mathrm{E} 2=721.2 \mathrm{eV}$ and fixed widths of $\mathrm{w} 1=\mathrm{w} 2=1 \mathrm{eV}$. The calculated double arctan background-functions were subtracted from the signal integration window of each analysis. Fe-oxidation states were determined by the universal curve as a function of the integral ratio of $\mathrm{Fe} L_{3} / L_{2}$ and the total ferric Fe concentration (van Aken et al., 1998). EELS (50 signals) were collected for each sample and then summated.

\section{Results and discussions}

\subsection{Core description}


The split cores of sites U1365 and U1369 were scanned by Section Half Imaging Logger (SHIL) (IODP-USIO) and described based on the optical observation of smear slides of sediments with increasing depth (Fig. 2). The sediment column at U1365 is subdivided into four lithological units; 1) zeolitic metalliferous pelagic clay (unit IA; 0-8.35 mbsf), 2) metalliferous pelagic clay to zeolitic metalliferous pelagic clay (unit IB; 8.35-43.7 mbsf), 3) porcelanite and chert (unit II; 43.7-62.3 mbsf), and 4) metalliferous clay (unit III; 62.3-75.3 mbsf). In the subunit IA, proportions of clay decrease from $30 \%$ to $20 \%$, and zeolite abundance increases from $10 \%$ to $40 \%$, while both clay and Red-brown to yellow-brown Semiopaque Oxide minerals (RSO) vary erratically (10\% to $50 \%$ ) with a depth. Sediment in unit II includes chert, porcelanite and inter-bedded pelagic sediment. The mineral proportion of both clay and zeolite minerals decreases relative to unit I, while RSO increases from $20 \%$ to $90 \%$. Unit III consists of black colored metalliferous clays with a high proportion of RSO. The unit located just above the basalt contact is distinctively colored compared to the brown and dark brown sediment in the upper units. The sediment column at U1369 is subdivided into two lithological units; 1) metalliferous zeolitic pelagic clay (unit I; 0 - $5.3 \mathrm{mbsf}$ ), and 2) zeolitic metalliferous pelagic clay (unit II; 5.3 - $15.6 \mathrm{mbsf}$ ). In the unit I, brown-yellowish sediment includes of zeolite less than $10 \mu \mathrm{m}$ in length (38 - $63 \%)$, RSO (24 - $38 \%)$ and clays $(\sim 13 \%)$ whose abundances vary with depth. In unit II, dark brown sediment contains clay $(9-15 \%)$, RSO (42\%) and zeolite crystals that are greater than $50 \mu \mathrm{m}$ in length $(35-$ $70 \%$ ). The existence of chert layers at a depth of 43.7-62.3 mbsf of U1365 indicated a high biological productivity and high temperature of seawater (Keene, 1975; Muttoni and Kent, 2007). Dark black colored sediment appeared at the basal contact may indicate the alteration of basalt with seawater. Aeolian or terrigenous sediment may cause the variation of 
mineralogy for site U1365, far away from the center of gyre comparing with U1369.

\section{2. $X$-ray diffraction $(X R D)$}

XRD analyses of fine clay-sized sediment $(<1 \mu \mathrm{m})$ were performed from different depths at sites U1365 and U1369 (Fig. 3). Air-dried and ethylene-glycolated samples were examined to confirm the contents of smectite, chlorite, and kaolinite. The heterogeneous suite of clay minerals identified by XRD in the unit I (U1365) includes smectite (S), kaolinite (K) and illite (I) as well as clay-sized quartz (Q) and plagioclase (P). Smectite appears prominently through the depths of 4.59 - 42.8 mbsf compared with illite (4.59 - $34.86 \mathrm{mbsf}$ ), and kaolinite (4.59 - $17.49 \mathrm{mbsf})$. In unit III, goethite $(\mathrm{G})$ and plagioclase $(\mathrm{P})$ are present at depths between 71.83 and 75.16 mbsf. The discernible XRD reflections was not observed due to the amorphous RSO found in virtually all intervals of unit III. Because chert layers were identified in all intervals of the cores of unit II (43.7 - $62.3 \mathrm{mbsf}$ ) by visual observation, XRD was not performed for this unit. At site U1369, XRD diffractograms imply that illite (I), smectite (S), kaolinite (K), and chlorite (Ch) appear abundantly throughout all depths (1.16 $15.52 \mathrm{mbsf})$ with minor amounts of plagioclase $(\mathrm{P})$, phillipsite $(\mathrm{Ph}), \mathrm{K}$-feldspar $(\mathrm{Kf})$ and goethite (G). XRD profiles for glycolated samples confirmed the occurrence of smectite and chlorite at U1369. The abundant, uniform occurrence of illite, chlorite, and kaolinite throughout all depths of sediment at site U1369 compared with the lower abundance and limited distribution at site U1365 (Fig. 3) indicates that the hydrothermal activity (Deer et al., 1996; Dekov et al., 2005) that aids in the formation of illite, chlorite, and kaolinite. These variations may result from differences in the pattern and magnitude of hydrothermal 
circulation and advective heat flow. The observed heat flow at site U1369 is $18 \mathrm{~mW} / \mathrm{m}^{2}$, a value very low for its crustal age relative to conductive cooling models (Stein and Stein, 1994) and is highly indicative of ongoing fluid flow. In contrast, the observed heat flow at site $\mathrm{U} 1365$ is $58 \mathrm{~mW} / \mathrm{m}^{2}$, a value that is consistent with conductive cooling models for its crustal age.

\subsection{Pore water chemistry}

To explore the source of smectite and illte mineral variability at sites U1365 and U1369, the role of pore water was more fully considered. Pore water chemistry, including dissolved oxygen (DO), silicon $\left(\mathrm{Si}^{4+}\right)$, potassium $\left(\mathrm{K}^{+}\right)$, iron $\left(\mathrm{Fe}^{\text {tot }}\right)$, and nitrate $\left(\mathrm{NO}_{3}{ }^{-}\right)$are provided by Expedition 329 Scientists (2011) (Fig. 4). At site U1365, DO profile decreases from $189.5 \mu \mathrm{M}$ at the surface of sediment to $69.7 \mu \mathrm{M}$ at the sediment/basalt contact. Dissolved $\mathrm{Si}^{4+}$ drastically increases from approximately $350 \mu \mathrm{M}$ at the sediment/water interface up to $601 \mu \mathrm{M}$ at $42.18 \mathrm{mbsf}$ where chert and porcelanite layers (unit II) appear, $\mathrm{Si}^{4+}$ then decreases to $465 \mu \mathrm{M}$ at the sediment/basalt contact $(75.5 \mathrm{mbsf}) . \mathrm{K}^{+}$concentration fluctuates within the upper part of unit I (21.8 mbsf), and increases up to $15.4 \mathrm{mM}$ at the lower part of unit I (42.18 mbsf). Below unit II (62.3 mbsf), the $\mathrm{K}^{+}$concentrations appear nearly constant $(\sim 12 \mathrm{mM})$. Fe ${ }^{\text {tot }}$ concentration increases in value slightly with increasing depth. It achieves its peak value of $5.2 \mu \mathrm{M}$ at the contact with the basaltic basement. The concentration of $\mathrm{NO}_{3}{ }^{-}$increases continuously from the sediment/water interface to the basal boundary of unit I (38.46 $\mu \mathrm{M}$ to $48.17 \mu \mathrm{M})$; however, $\mathrm{NO}_{3}{ }^{-}$values in unit III, below the chert and porcelanite layers of unit II, show a increase in concentration ( $33.3 \mu \mathrm{M}$ to $38.65 \mu \mathrm{M}$, see solid arrow), relative to similar sediment found in unit I. At the site U1369, the concentration 
of DO shows a slight decrease $(157.6 \mu \mathrm{M}$ to $118 \mu \mathrm{M})$ with increasing depth except near the sediment/basalt interface at $12.8 \mathrm{mbsf}$ to $15.6 \mathrm{mbsf}$ where oxygen values rebound from a low of $118 \mu \mathrm{M}$ back to $136.1 \mu \mathrm{M}$. $\mathrm{Si}^{4+}$ concentrations fluctuate, slightly increasing with depth (240.8 $\mu \mathrm{M}$ to $276.4 \mu \mathrm{M}$ ). The $\mathrm{K}^{+}$concentration appears constant throughout the entire sequence of sediment with only some minor fluctuation $(12.16 \mathrm{mM}$ to $12.69 \mathrm{mM}) . \mathrm{Fe}^{\text {tot }}$ also appears largely invariable, with values that are nearly constant in the range of $7.47 \mu \mathrm{M}$ to $6.78 \mu \mathrm{M}$. Similar to the upper sections of $\mathrm{U} 1365, \mathrm{NO}_{3}{ }^{-}$increases continuously from approximately $38 \mu \mathrm{M}$ to $41.2 \mu \mathrm{M}$. Contrary to the trend at $\mathrm{U} 1365, \mathrm{NO}_{3}{ }^{-}$at site $\mathrm{U} 1369$ shows a slight increase ( $40.3 \mu \mathrm{M}$ to $41.2 \mu \mathrm{M}$, see open arrow) at the sediment/basalt interface.

DO profiles indicate that an oxidative environment persists throughout the sedimentary sequence as well as through the upper portions of the basaltic basement (Fig. 4). At site U1365, this observations is particularly noteworthy where thick chert layers $(\sim 20 \mathrm{~m})$ likely impede or block the downward penetration of DO below unit II. RSO, an amorphous oxide that is sensitive to redox conditions, is abundant in the sediment immediately overlying the basalt contact at U1365 (Fig. 2). However, the amorphous Fe-oxyhydroxides could be a result of oxidation of dissolved Fe in hydrothermal fluids upon their mixing with oxygenated seawater (Millero et al., 1987; Pichler and Veizer, 1999). The likely cause of this pervasive oxygen is diffusion of oxygen from fractured basaltic crust into overlying sediment (Orcutt $e t$ al., 2013). D'hondt et al. (2015) speculate that this process has occurred throughout the entire SPG depositional history. Indeed, the observed concentration of DO at site U1369 actually shows a slight increase at the sediment/basalt interface ( $\sim 14 \mathrm{mbsf}$ to $\sim 15 \mathrm{mbsf})$, and therefore, diffusion appears to be ongoing.

\subsection{Transmission electron microscopy (TEM)}


Bright-field TEM micrographs of clay minerals, including insets of corresponding EDS and SAED patterns, are displayed (Figs. 5 and 6). TEM images of clay packets ( $30 \mathrm{~nm}$, see circled area) in the upper part of unit I (4.59 mbsf) at site U1365 show a wavy structure with diffused corresponding SAED patterns and the elemental composition of the circled area $(\mathrm{Al} / \mathrm{Si}=0.32, \mathrm{Fe} / \mathrm{Si}=0.13, \mathrm{Mg} / \mathrm{Si}=0.13)$ indicating Fe-montmorillonite (Fig. 5a). Neighboring discrete clay packets (circled area, $50 \mathrm{~nm}$ in thickness) show the elemental compositions $(\mathrm{Al} / \mathrm{Si}=0.58, \mathrm{~K} / \mathrm{Si}=0.04)$ typical of illite $($ Fig. $5 \mathrm{~b})$. With $\mathrm{d}_{001}=1.0 \mathrm{~nm}$ in the OOl Bragg reflections and diffused $1.0 \mathrm{~nm}$ spacings in $02 \mathrm{l}$ reflections row, these packets are likely disordered illite, polytype $1 M_{d}$ (Fig. 5b). In unit III, fibrous and wavy smectite layers mixed with rounded $\mathrm{Fe} / \mathrm{Mn}$ oxides prevail at the sediment/basaltic crust interface $(75.52$ mbsf). SAED and EDS results (Fig. 5c) reveal that clay in this unit includes Fe-rich smectite $(\mathrm{Al} / \mathrm{Si}=0.11, \mathrm{Fe} / \mathrm{Si}=0.18)$ with diffused turbostratically disordered smectite Bragg's reflections $\left(\mathrm{d}_{100}=0.45 \mathrm{~nm}\right)$. The abundance of iron in unit III is further supported by the presence of both goethite $\left(\mathrm{d}_{110}=0.42 \mathrm{~nm}, \mathrm{~d}_{111}=0.25\right)$, and hematite that are readily identifiable in XRD diffractograms obtained from samples from this interval (Expedition 329 Scientists, 2011).

TEM micrograph of clay packets in the lower part of sediment column (15.52 mbsf) at site U1369 shows a wavy structure with diffused SAED patterns $\left(\mathrm{d}_{001}=1.2 \mathrm{~nm}\right)$ and the elemental composition of the circled area (Fig. 6a) shows a high $\mathrm{Fe}$-content $(\mathrm{Al} / \mathrm{Si}=0.48$, $\mathrm{Fe} / \mathrm{Si}=0.22$ ) indicating Fe-rich smectite (nontronite). Variations in the illite polytypes found at U1369 are displayed in the SAED patterns of discrete clay packets $(30-80 \mathrm{~nm}$ in thickness) with high $\mathrm{Al} / \mathrm{Si}$ and $\mathrm{K} / \mathrm{Si}$ contents $(\mathrm{Al} / \mathrm{Si}=0.65-0.73, \mathrm{~K} / \mathrm{Si}=0.07-0.12)(\mathrm{Figs}$. 6b, 6c, 6d). Three illite polytypes were identified: 
1) $1 M$, an ordered 1-layer polytype displaying distinct $00 l$ reflections $\left(\mathrm{d}_{001}=1.0 \mathrm{~nm}\right)$ and the repeated $1.0 \mathrm{~nm}$ spacings in $02 l$ reflections row (Fig. 6b);

2) $2 M_{1}$, an ordered 2-layer polytype exhibiting $00 l$ reflections $\left(\mathrm{d}_{001}=1.0 \mathrm{~nm}\right)$ with a well-defined repetition of $2.0 \mathrm{~nm}$ spacings in $02 l$ reflections rows (Fig. 6c);

3) 3T, an ordered 3-layer polytype showing $00 l$ reflections with $d_{001}=1.0 \mathrm{~nm}$ and well-defined repetition of $3.0 \mathrm{~nm}$ spacings in $02 l$ reflections rows (Fig. 6d).

Bright-field TEM micrographs of clay minerals from the sediment near the basaltic crust at sites U1365 and U1369 show a presence of K-bearing Fe-rich smectite (Fig. 7). TEM images of clay minerals in the lower part of unit III (70.16 mbsf) at site U1365 show an aggregation of clay packets (Fig. 7a). The elemental composition of the circled area shows ratios of $(\mathrm{Al} / \mathrm{Si}=0.17, \mathrm{~K} / \mathrm{Si}=0.08, \mathrm{Fe} / \mathrm{Si}=0.52)$, consistent with $\mathrm{K}$-bearing Fe-rich nontronite. Clay packets from a similar interval at site U1369 (unit II, $15.52 \mathrm{mbsf}$ ), also show prominent $\mathrm{K}$ content $(\mathrm{Al} / \mathrm{Si}=0.36, \mathrm{~K} / \mathrm{Si}=0.06, \mathrm{Fe} / \mathrm{Si}=0.32)$, Fe-rich nontronite $(\mathrm{Fig} .7 \mathrm{~b})$.

Hydrothermal activity is reflected in the illite polytypes $\left(1 M, 2 M_{1}\right.$, and $\left.3 T\right)$ at site U1369 compared with U1365. Illite polytypes $2 M_{1}$ and $3 T$, in particular, are commonly associated with hydrothermal processes: polytype $2 M_{l}$, for example, is reported in hydrothermally altered subseafloor sediments from the Aleutian trench (DSDP 180) (Eslinger and Yeh, 1981) and in subseafloor hemipelagic mud from the Chile Triple Junction trench (Kurnosov et al., 1995). The highly ordered illite polytype, 3T, on the other hand, has been synthesized in a lab-scale hydrothermal condition (Warshaw, 1960) and detected in a hydrothermal vein system in the Creede mining district, Colorado, USA (Horton, 1983). The preponderance of beidellite and saponite at site U1369 close to EPR is strongly indicative of hydrothermal origins associated with active mid-ocean ridges (Parra et al., 1985, 1986; Fagel et al., 2001), as previously reported for northern North Atlantic sediment (Fagel et al., 2001). 
However, the smectite found in site U1365, where Fe-rich nontronite and RSO coexist within metalliferous sediment located near the sediment/basalt contact, is likely the product of nonhydrothermal processes. The deposition of smectite in SPG pelagic sediment also likely due to the terrigenous input. The Fe-rich montmorillonite in the upper part of site U1365 sediment seems to be an influx of terrestrial component (Aoki et al., 1979; Fagel et al., 2007), or alteration of volcanic ash (Peterson and Griffin, 1964) because the location of site U1365 is close to the continental margin. Indeed, Fe-rich montmorillonite does not appear in the sediments of site U1369 near the EPR, where the hydrothermal alteration or seawater/basalt alteration are likely to be a dominant process, resulting in the formation of Fe-rich nontronite, thermodynamically favored relative to the other clay minerals.

\subsection{Electron Energy Loss Spectroscopy (EELS)}

Clay samples from sites U1365 and U1369 were examined by TEM-EELS (Fig. 8a). The Fe $L_{3}$ and $L_{2}$ edges appear near 708 and $721 \mathrm{eV}$. The integral ratio of $\mathrm{Fe} L_{3} / L_{2}$ in samples with substantial K were calculated by statistical analysis in Digital Micrograph software as 4.38 and 1.88 for sites U1365 (74.04 mbsf) and U1369 (15.52 mbsf), respectively. The corresponding percentages of $\mathrm{Fe}(\mathrm{III})$, estimated by means of the universal curve as a function of integral white-line ratio of $\mathrm{Fe} L_{3} / L_{2}$ versus Fe(III) concentration, are thus $\sim 47 \%$, and $\sim 4$, (Fig. 8b). The sample of Fe-rich smectite (nontronite) without K-content in the metalliferous sediment (Fig. 5c) contains more Fe(III) significantly ( 78\%) (Fig. 8b).

The accuracy of the estimated concentrations of $\mathrm{Fe}$ (III) in the nontronite of sites U1365 and U1369 are assessed by two means: First, the results are compared to the integral ratio of $\mathrm{Fe} L_{3} / L_{2}$ of well characterized bioreduced nontronite (77.8 \% of $\mathrm{Fe}$ (III) for 6-month 
bioreduced NAu-1 measured by 1-10 phenanthroline) as determined by Koo et al., (2014). Their results ( $\mathrm{Fe} L_{3} / L_{2}=6.82,78 \%$ ) Fe(III)) show strong similarity to those presented herein; both sets of results fall on the fit line of van Aken et al., (1998). Secondly, our results confirm with hematite crystals for $100 \% \mathrm{Fe}(\mathrm{III})$ standard obtained from site U1371 (Mitsunobu et al., 2012). Their data, based on micro-XANES analysis, also plots on the van Aken et al., (1998) universal curve, with Fe $L_{3} / L_{2}=9.58$ corresponding to the $100 \%$ ferric iron (Fig. 8 b).

Regardless of thermal history of sediment or location, K-bearing nontronite exists only in sediment located near crustal basalt (Fig. 7), suggesting the in-situ formation of smectite from basalt alteration with sea water. Since the unaltered basalt contains low $\mathrm{K}$ in the study area (Zhang et al., 2012), seawater is the most likely source of K (Fig. 4). The mechanism of $\mathrm{K}$ uptake is likely by diffusive exchange with seawater in the presence of dissolved oxygen (Clayton et al., 2000). However, the mechanism of K-fixation into the nontronite structure is not fully understood due to the following observations: 1) the Fe(III) measured by EELS on the K-nontronite in basal sediment shows a range of $4-47 \%$ (Fig. 8) promoting K-fixation into the more negatively charged nontronite compared with ferric dominant nontronite; 2) the composition of basalts immediately underlying the sediment are marked by a dominant (60\% $66 \%$ ) Fe(III) phase (Zhang et al., 2012), however the reactions of basalt alteration that lead to nontronite formation could change in the Fe-redox state; and 3) the redox state of Fe in nontronite is ferric ( 78\%) (Fig. 8b). Consequently, a redox reaction -in direct opposition to an oxidative diffusive exchange- is needed to explain the observed $\mathrm{Fe}(\mathrm{II})$ found in these K-bearing nontronites.

The reduced $\mathrm{Fe}$ in $\mathrm{K}$-nontronite could result from local microbially mediated $\mathrm{Fe}$ reduction. The less negatively charged nontronite associated with Fe-reduction has a strong tendency to fix $\mathrm{K}$ into the interlayer to balance the layer charge (Kim et al., 2004 and Koo et 
al., 2014). The microbial Fe(III) reduction in nontronite in marine sediment, a possible mechanism for the liberation of $\mathrm{Fe}(\mathrm{II})$ in anoxic environments, was previously reported (Vorhies and Gaines, 2009). Microbial activity, particularly Fe-respiration, is widely suspected of causing alterations in clay chemistry, structure and $\mathrm{Fe}(\mathrm{II})$ content (Kostka et al., 1996; Gates et al., 1998; Kostka et al., 1999a, b; Kim et al., 2004; Stucki, 2006; Dong et al., 2009). In the present study, microbes from the sediment/basalt contact were insufficiently cultured to test the effect of their activity on subseafloor redox conditions (D'hondt et al., 2015). Nonetheless, biotic redox reaction by microbial Fe-respiration cannot be excluded as a probable cause of the spatial variability of clay mineral in the SPG. Metagenome analysis for denitrification genes suggests that anoxic/hypoxic microenvironments may persist locally in the subseafloor sediment (Tully et al., 2016). Recently, K-nontronite was clearly identified as an intermediate phase of illite in the interaction of Fe-reducing microbe and Fe-rich nontronite when $35-43 \%$ of microbial Fe-reduction in nontronite was reached (Koo et al., 2014). Furthermore, in sites U1365 and U1369, the slight increases in nitrate concentration in the sediment and basal basalt contacts $(33.3 \mu \mathrm{M}$ to $38.65 \mu \mathrm{M}$ for site $\mathrm{U} 1365$ and $40.3 \mu \mathrm{M}$ to 41.2 $\mu \mathrm{M}$ for site U1369, see arrows in Fig. 4e) are possibly caused by ammonium oxidation coupled with Fe-reduction in a process known as "feammox" or through the oxidation of reduced nitrogen species (Yang et al., 2012). However, because the concentrations of ammonium for both sites were below their limits of detection, the exact cause of variations in the concentrations of nitrate are not determined (D'hondt et al., 2011; Zehr et al., 2011).

\section{Conclusions}

A series of microscopic, spectroscopic, and chemical analyses of clay minerals in 
subseafloor sediment beneath the SPG reveals that clay mineral compositions were resulted from various origins/mechanisms of clay mineral formation in the open ocean. Illite polytypes provide snapshots of hydrothermal activity in sediment, and variation of $\mathrm{Fe}(\mathrm{II}) / \mathrm{Fe}(\mathrm{III})$ in nontronite and the appearance of K-nontronite at the basal basalt/sediments interface suggest that local reductive reaction occurs during the formation of K-nontronite despite the fact that dissolved oxygen prevails throughout the sediment column down to the basaltic basement. It is particularly worthy of note that the variability of clay mineral structure and composition identified by this study was formed under pervasive/persistent oxic conditions.

\section{Acknowledgements}

We would like to thank the scientific parties of IODP expedition 329 for their indispensable discussions and comments. This research was a part of the project titled 'International Ocean Discovery Program', funded by the Ministry of Oceans and Fisheries, Korea. HRTEM analyses were supported by Korea Basic Science Institute (KBSI) project (T35520), and partially supported by DOE grand to H. Dong (G01928). 


\section{References}

Anderson, R.N., 1986. Marine geology: A planet earth perspective. Wiley \& Sons, New York, pp. 328

Aoki, S., Kohyama, N., Sudo, T., 1979. Mineralogical and chemical properties of smectites in a sediment core from the southeastern Pacific. Deep Sea Research Part A. Oceanographic Research Papers 26 (8), 893-902.

Biscaye, P.E., 1965. Mineralogy and sedimentation of recent deep-sea clay in the Atlantic Ocean and adjacent seas and oceans. Geological Society of America Bulletin 76 (7), 803-832.

Chamley, H., 1989. Clay Minerals. Clay Sedimentology, Springer Berlin Heidelberg, pp. 3-20.

Claustre, H., Maritorena, S., 2003. The many shades of ocean blue. Science 302 (5650), 1514-1515.

Clayton, T., Pearce, R.B., 2000. Alteration mineralogy of Cretaceous basalt from ODP Site 1001, Leg 165 (Caribbean Sea). Clay Minerals 35 (4), 719-733.

Cole, T. G., 1988. The nature and origin of smectite in the Atlantis II Deep, Red Sea. The Canadian Mineralogist 26 (4), 755-763.

Cuadros, J., Dekov, V. M., \& Fiore, S., 2008. Crystal chemistry of the mixed-layer sequence talc-talc-smectite-smectite from submarine hydrothermal vents. American Mineralogist, 93(8-9), 1338-1348.

Cuadros, J., Dekov, V.M., Arroyo, X., Nieto, F., 2011. Smectite formation in submarine 
hydrothermal sediments: samples from the HMS challenger expedition (1872-1876). Clays and Clay Minerals 59 (2), 164-164.

Cuadros, J., Michalski, J. R., Dekov, V., Bishop, J., Fiore, S., \& Dyar, M. D., 2013. Crystalchemistry of interstratified $\mathrm{Mg} / \mathrm{Fe}$-clay minerals from seafloor hydrothermal sites. Chemical Geology, 360, 142-158.

Deer, W.A., Howie, R.A., Zussman, J., 1996. Non-silicates: Sulphates, Carbonates, Phosphates and Halides. An introduction to Rock-forming minerals, 5.

Dekov, V. M., Scholten, J., Botz, R., Garbe-Schönberg, C. D., Thiry, M., Stoffers, P., \& Schmidt, M., 2005. Occurrence of kaolinite and mixed-layer kaolinite/smectite in hydrothermal sediments of Grimsey Graben, Tjörnes Fracture Zone (north of Iceland). Marine geology, 215(3), 159-170.

Dekov, V. M., Cuadros, J., Shanks, W. C., \& Koski, R. A., 2008. Deposition of talckerolite-smectite-smectite at seafloor hydrothermal vent fields: Evidence from mineralogical, geochemical and oxygen isotope studies. Chemical Geology, 247(1), 171-194.

D’Hondt, S., Spivack, A.J., Pockalny, R., Ferdelman, T.G., Fischer, J.P., Kallmeyer, J., Abrams, L.J., Smith, D.C., Graham, D., Hasiuk, F., Schrum, H., Stancin, A.M., 2009. Subseafloor sedimentary life in the South Pacific Gyre. Proceedings of the National Academy of Sciences of the United States of America 106 (28), 11651-11656.

D’Hondt, S., Abrams, L.J., Anderson, R., Dorrance, J., Durbin, A., Ellett, L., Ferdelman, T., Fischer, J., Forschner, S., Fuldauer, R., 2011. KNOX-02RR: drilling site survey-life 
in subseafloor sediments of the South Pacific Gyre 1. Proceedings of Integrated Ocean Drill Program 329, 1-82.

D’Hondt, S., Inagaki, F., Zarikian, C.A., Abrams, L.J., Dubois, N., Engelhardt, T., Evans, H., Fedelman, T., Gribsholt, B., Harris, R.N., Hoppie, B.W., Hyun, J., Kallmeyer, J., Kim, J., Lynch, J.E., McKinley, C.C., Mitsunobu, S., Morono, Y., Murray, R.W., Pockalny, R., Sauvage, J., Shimono, T., Shiraishi, F., Smith, D.C., Smith-Duque, C.E., Spaivack, A.J., Steinsbu, B.O., Suzuki, Y., Szpak, M., Toffin, L., Uramoto, G., Yamaguchi, Y.T., Zhang, G., Zhang, X., Ziebis, W., 2015. Presence of oxygen and aerobic communities from seafloor to basement in deep-sea sediment. Nature Geoscience 8, 299-304.

DiMarco, M.J., Ferrell, R.E., Lowe, D.R., 1989. Polytypes of 2:1 dioctahedral micas in silicified volcaniclastic sandstones, Warrawoona Group, Pilbara Block, Western Australia. American Journal of Science, 289(5), 649-660.

Dong, H., Jaisi, D.P., Kim, J., Zhang, G., 2009. Microbe-clay mineral interactions. American Mineralogist 94 (11-12), 1505-1519.

Eslinger, E., Highsmith, P., Albers, D., DeMayo, B., 1979. Role of iron reduction in the conversion of smectite to illite in bentonites in the Disturbed Belt, Montana. Clays and Clay Minerals 27 (5), 327-338.

Eslinger, E.V., Yeh, H.W., 1981. Mineralogy, O18/O16 and D/H ratios of clay-rich sediments from Deep-Sea Drilling Project site 180, Aleutian Trench. Clays and Clay Minerals 29 (4), 309-315. 
Expedition 329 Scientists., 2011. South Pacific Gyre subseafloor life. Proceedings of Integrated Ocean Drilling Program 329, 1-108.

Fagel, N., Robert, C., Preda, M., Thorez, J., 2001. Smectite composition as a tracer of deep circulation: the case of the Northern North Atlantic. Marine Geology 172 (3), 309330.

Fagel, N., 2007. Chapter Four Clay Minerals, Deep Circulation and Climate. Developments in Marine Geology, 1, 139-184.

Gates, W.P., Jaunet, A., Tessier, D., Cole, M.A., Wilkinson, H.T., Stucki, J.W., 1998. Swelling and texture of iron bearing smectites reduced by bacteria. Clays and Clay Minerals $46(5), 487-497$.

Glasby, G.P., 1991. Mineralogy, geochemistry, and origin of Pacific red clays: a review. New Zealand Journal of Geology and Geophysics 34 (2), 167-176.

Gradstein, F.M., Ogg, J.G., Smith, A.G., 2004. A Geologic Time Scale 2004: Cambridge, Cambridge Univ. Press.

Haggerty, S.E., Baker, I., 1967. The alteration of olivine in basaltic and associated lavas. Contributions to mineralogy and petrology 16 (3), 233-257.

Hart, S.R., Erlank, A.J., Kable, E.J.D., 1974. Sea floor basalt alteration: some chemical and Sr isotopic effects. Contributions to Mineralogy and Petrology 44 (3), 219-230.

Horton, D.G., 1983. Argillic alteration associated with the Amethyst vein system, Creede mining district, Colorado. Ph. D. Thesis, 1, 23. 
Inoue, A., Velde, B., Meunier, A., Touchard, G., 1988. Mechanism of illite formation during smectite-to-illite conversion in a hydrothermal system. American Mineralogist 73, $1325-1334$.

Jackson, M.L., 1969. Soil Chemical Analysis-Advanced Course, Dept. Soil Sci, University of Wisconsin, Madison, WI.

Jaisi, D.P., Kukkadapu, R.K., Eberl, D.D., Dong, H., 2005. Control of Fe (III) site occupancy on the rate and extent of microbial reduction of Fe (III) in nontronite. Geochimica et Cosmochimica Acta 69 (23), 5429-5440.

Jaisi, D.P., Dong, H., Liu, C., 2007a. Influence of biogenic Fe (II) on the extent of microbial reduction of $\mathrm{Fe}$ (III) in clay minerals nontronite, illite, and chlorite. Geochimica et Cosmochimica Acta 71 (5), 1145-1158.

Jaisi, D.P., Dong, H., Liu, C., 2007b, Kinetic analysis of microbial reduction of Fe (III) in nontronite. Environmental science \& technology 41 (7), 2437-2444.

Jaisi, D.P., Eberl, D.D., Dong, H., Kim, J., 2011. The formation of illite from nontronite by mesophilic and thermophilic bacterial reaction. Clays and Clay Minerals 59 (1), 2133.

Keene, J. B., 1975. Cherts and porcellanites from the North Pacific, DSDP Leg 32. Initial Reports of the Deep Sea Drilling Project, 32, 429-507.

Kim, J.W., Peacor, D.R., Tessier, D., Elsass, F., 1995. A technique for maintaining texture and permanent expansion of smectite interlayers for TEM observations. Clays and Clay Minerals 43 (1), 51-57. 
Kim, J.W., Furukawa, Y., Daulton, T.L., Lavoie, D., Newell, S.W., 2003. Characterization of microbially $\mathrm{Fe}$ (III)-reduced nontronite: environmental cell-transmission electron microscopy study. Clays and Clay Minerals 51 (4), 382-389.

Kim, J.W., Dong, H., Seabaugh, J., Newell, S.W., Eberl, D.D., 2004. Role of microbes in the smectite-to-illite reaction. Science 303 (5659), 830-832.

Kim, J., Dong, H., 2011. Application of electron energy-loss spectroscopy (EELS) and energy-filtered transmission electron microscopy (EFTEM) to the study of mineral transformation associated with microbial Fe-reduction of magnetite. Clays and Clay Minerals 59 (2), 176-188.

Koo, T.H., Jang, Y.N., Kogure, T., Kim, J.H., Park, B.C., Sunwoo, D., Kim, J.W., 2014. Structural and chemical modification of nontronite associated with microbial Fe (III) reduction: Indicators of "illitization”. Chemical Geology 377, 87-95.

Kostka, J.E., Stucki, J.W., Nealson, K.H., Wu, J., 1996. Reduction of structural Fe (III) in smectite by a pure culture of Shewanella putrefaciens strain MR-1. Clays and Clay Minerals 44 (4), 522-529.

Kostka, J.E., Haefele, E., Viehweger, R., Stucki, J.W., 1999a. Respiration and dissolution of iron (III)-containing clay minerals by bacteria. Environmental Science \& Technology $33(18), 3127-3133$.

Kostka, J.E., Wu, J., Nealson, K.H., Stucki, J.W., 1999b. The impact of structural Fe (III) reduction by bacteria on the surface chemistry of smectite clay minerals. Geochimica et Cosmochimica Acta 63 (22), 3705-3713. 
Kurnosov, V., Murdmaa, I., Chamov, N., Chudaev, O., Eroshchev-Shak, V., Shterenberg, L., 1995, Mineralogy of sediments from the chile triple junction. Proceedings of the Ocean Drilling Program, Scientific Results 141, 95-104.

Marsaglia, K., Milliken, K., and Doran, L., 2013. IODP digital referece for smear slide analysis of marine mud. Part 1: Methodology and atlas of siliciclastic and volcanogenic components. IODP Technical Note 1.

Malcolm, R.L., 1968. Freeze-drying of organic matter, clays, and other earth materials. US Geol. Survey Prof. Paper, C211-C216.

Manheim, F.T., Sayles, F.L., 1974. Composition and origin of interstitial waters of marine sediments, based on deep sea drill cores. The Sea 5, 527-568.

McMurtry, G. M., Chung-Ho, W., \& Hsueh-Wen, Y., 1983. Chemical and isotopic investigations into the origin of clay minerals from the Galapagos hydrothermal mounds field. Geochimica et Cosmochimica Acta, 47(3), 475-489.

Millero, F. J., Sotolongo, S., \& Izaguirre, M., 1987. The oxidation kinetics of Fe (II) in seawater. Geochimica et Cosmochimica Acta, 51(4), 793-801.

Mitsunobu, S., Suzuki, Y., Kim, J.W., 2012. Analysis of secondary mineral found at basaltsediment interface by $\mu$-XAFS, EPMA, and TEM. IODP 331 and 329 joint postcruise meeting. 12th-14th November, Kona, Hawaii. Poster Presentation.

Muttoni, G., \& Kent, D. V., 2007. Widespread formation of cherts during the early Eocene climate optimum. Palaeogeography, Palaeoclimatology, Palaeoecology, 253(3), $348-362$. 
Nespolo, M., 2001. Perturbative theory of mica polytypism. Role of the M2 layer in the formation of inhomogeneous polytypes. Clays and clay minerals 49 (1), 1-23.

Orcutt, B.N., Wheat, C.G., Rouxel, O., Hulme, S., Edwards, K.J., Bach, W., 2013. Oxygen consumption rates in subseafloor basaltic crust derived from a reaction transport model. Nature communications 4, 1-7.

Parkhurst, D.L., Appelo, C.A.J., 1999. User's guide to PHREEQC (Version 2): A computer program for speciation, batch-reaction, one-dimensional transport, and inverse geochemical calculations.

Parra, M., Delmont, P., Ferragne, A., Latouche, C., Puechmaille, J.P.A., 1985. Origin and evolution of smectite in recent marine sediments of the NE Atlantic. Clay Minerals $20,335-346$.

Parra, M., Puechmaille, C., Dumon, J. C., Delmont, P., Ferragne, A., 1986. Geochemistry of tertiary alterite clay phases on the Iceland-Faeroe ridge (Northeast Atlantic), Leg 38, Site 336. Chemical geology 54 (1), 165-176.

Peterson, M.N.A., Griffin, J.J., 1964. Volcanism and clay minerals in the southeastern Pacific. Journal of marine research 22 (1), 13-21.

Pichler, T., \& Veizer, J., 1999. Precipitation of Fe (III) oxyhydroxide deposits from shallowwater hydrothermal fluids in Tutum Bay, Ambitle Island, Papua New Guinea. Chemical Geology, 162(1), 15-31.

Piper, D.Z. Swint, T.R. Sullivan, L.G., McCoy, F.W., 1985. Manganese nodules, seafloor sediment, and sedimentation rates of the Circum-Pacific region. Circum-Oacific 
Council for Energy and Mineral Resources chart.

Seabaugh, J.L., Dong, H., Kukkadapu, R.K., Eberl, D.D., Morton, J.P., Kim, J., 2006. Microbial reduction of $\mathrm{Fe}$ (III) in the Fithian and Muloorina illites: contrasting extents and rates of bioreduction. Clays and Clay Minerals 54 (1), 67-79.

Singer, A., Stoffers, P., Heller-Kallai, L., Szafranek, D., 1984. Nontronite in a deep-sea core from the South Pacific. Clays and Clay Minerals 32 (5), 375-383.

Stein, C. A., \& Stein, S., 1994. Constraints on hydrothermal heat flux through the oceanic lithosphere from global heat flow. Journal of Geophysical Research: Solid Earth (1978-2012), 99(B2), 3081-3095.

Stucki, J.W., 1998. Swelling and texture of iron-bearing smectites reduced by bacteria. Clays and Clay Minerals 46 (5), 487-497.

Stucki, J.W., Kostka, J.E., 2006. Microbial reduction of iron in smectite. Comptes Rendus Geoscience 338 (6), 468-475.

Stuchi, J.W., 2011. A review of the effects of iron redox cycles on smectite properties. Comptes Rendus Geoscience 343 (2), 199-209.

Tully, B.J., Huber, J.A., Heidelberg, J.F., 2016. Metabolic Potential of Microbial Genomes Reconstructed from a Deep-Sea Olightrophic Sediment Metagenome. Ocean Science Meeting 2016. 21th-26 ${ }^{\text {th }}$ February, New Orleans, Louisiana, USA. Poster Presentation.

Van Aken, P.A., Liebscher, B., Styrsa, V.J., 1998. Quantitative determination of iron oxidation states in minerals using $\mathrm{Fe}$ L 2, 3-edge electron energy-loss near-edge structure 
spectroscopy. Physics and Chemistry of Minerals 25 (5), 323-327.

Velde, B., 1965. Phengite micas; synthesis, stability, and natural occurrence. American Journal of Science 263 (10), 886-913.

Vorhies, J.S., Gaines, R.R., 2009. Microbial dissolution of clay minerals as a source of iron and silica in marine sediments. Nature Geoscience 2, 221-225.

Warshaw, C.M., 1960. Experimental studies of illite. Proc. Seventh Natl. Clay Conf., Pergamon Press, London, pp. 303-316.

Weaver, C.E., 1989. Clays, muds, and shales: Developments in sedimentology 44, Elsevier, Amsterdam.

Williams, D.B., Carter, C.B., 2009. Transmission Electron Microscopy. Part 4: Spectroscopy. ( $2^{\text {nd }}$ ed.). Springer, New York.

Wilson, M. J. 1999. The origin and formation of clay minerals in soils: past, present and future perspectives. Clay Minerals, 34(1), 7-7.

Yang, W.H., Weber, K.A., Silver, W.L., 2012. Nitrogen loss from soil through anaerobic ammonium oxidation coupled to iron reduction. Nature Geoscience 5 (8), 538-541.

Yoder, H.S., 1959. Experimental studies on micas: a synthesis. In Proc Sixth Nation Conf. Clays and Clay Minerals. Pergamon Press, London, 42-60.

Zehr, J.P., Kudela, R.M., 2011. Nitrogen cycle of the open ocean: from genes to ecosystems. Annual Review of Marine Science 3, 197-225.

Zhang, G., Kim, J., Dong, H., Sommer, A.J., 2007a. Microbial effects in promoting the 
smectite to illite reaction: Role of organic matter intercalated in the interlayer. American Mineralogist 92 (8-9), 1401-1410.

Zhang, G., Dong, H., Kim, J., Eberl, D.D., 2007b. Microbial reduction of structural $\mathrm{Fe}^{3+}$ in nontronite by a thermophilic bacterium and its role in promoting the smectite to illite reaction. American Mineralogist 92 (8-9), 1411-1419.

Zhang, G., Smith-Duque, C., Tang, S., Li, H., Zarikian, C., D'Hondt, S., Inagaki, F., 2012. Geochemistry of basalts from IODP site U1365: Implications for magmatism and mantle source signatures of the mid-Cretaceous Osbourn Trough. Lithos 144, 73-87.

Zhou, W., Peacor, D.R., Alt, J.C., Van der Voo, R., Kao, L.S., 2001. TEM study of the alteration of interstitial glass in MORB by inorganic processes. Chemical Geology $174(1), 365-376$.

Zierenberg, R.A., Shanks, W.C., 1983. Mineralogy and geochemistry of epigenetic features in metalliferous sediment, Atlantis II Deep, Red Sea. Economic Geology 78 (1), 57-72. 


\section{Figure captions}

Fig. 1. Bathymetry map of the SPG showing drilling sites by IODP Expedition 329 (U1365 U1371). Sediments cored at sites U1365 and U1369 (outlined in red) were used for the present study.

Fig. 2. Lithology of the sediment columns for the sites U1365 and U1369. Mineral compositions are indicated by colors (green $=$ clay, gray $=$ zeolite, red $=\mathrm{RSO}$ ), and the insets of representative smear slide images show corresponding mineral compositions of pelagic sediment.

Fig. 3. XRD patterns of air dried and glycolated clay less than $1 \mu \mathrm{m}$ of the subseafloor sediment for the sites U1365 and U1369 at various depths displaying composition of smecitite $(\mathrm{S})$, chlorite $(\mathrm{Ch})$, kaolinite $(\mathrm{K})$, illite $(\mathrm{I})$, quartz $(\mathrm{Q})$, plagioclase $(\mathrm{P})$, phillipsite $(\mathrm{Ph})$, K-feldspar (Kf), and goethite (G).

Fig. 4. Pore water chemistry of sediment columns at the sites U1365 and U1369 (IODP expedition 329 scientists., 2011) showing (a) dissolved oxygen penetration down to sediment/basalt interface, (b) slightly increase in silicon with a depth and high silicon concentration around chert (U1365 unit II), (c) slightly increase in potassium concentration with a depth, (d) constant iron concentrations with a depth, and (e) increase in nitrate 
concentration with a depth (see arrows showing abrupt increase at sediment/basalt interface).

Fig. 5. Bright-field TEM micrographs of the fine clay fraction $(<1 \mu \mathrm{m})$ with the insets of EDS spectra and the corresponding SAED patterns (circled area) for the site U1365 sediments showing (a) Fe-montmorillonite (4.59 mbsf), wavy structures with diffused corresponding SAED patterns $\left(\mathrm{d}_{001}=1.3 \mathrm{~nm}\right)$, and elemental compositions $(\mathrm{Al} / \mathrm{Si}=0.32, \mathrm{Fe} / \mathrm{Si}=0.13) ;(\mathrm{b})$ $1 M_{d}$ illite $(4.59 \mathrm{mbsf})$, discrete packets with distinct Bragg's reflections $\left(\mathrm{d}_{001}=1.0 \mathrm{~nm}\right)$ and diffused $1.0 \mathrm{~nm}$ spacings in $02 l$ reflections row, and elemental compositions $(\mathrm{Al} / \mathrm{Si}=0.58$, $\mathrm{K} / \mathrm{Si}=0.04)$; and (c) Fe-rich smectite with Goethite (75.52 mbsf), wavy structures mixed with round shaped RSO, with turbostratically oriented SAED pattern of smectite $\left(\mathrm{d}_{100}=0.45\right.$ $\mathrm{nm})$ and goethite $\left(\mathrm{d}_{110}=0.42 \mathrm{~nm}, \mathrm{~d}_{111}=0.25\right)$ and the corresponding elemental composition of smectite $(\mathrm{Al} / \mathrm{Si}=0.11, \mathrm{Fe} / \mathrm{Si}=0.18)$

Fig. 6. Bright-field TEM micrographs of the fine clay fraction $(<1 \mu \mathrm{m})$ with the insets of EDS spectra and the corresponding SAED patterns (circled area) for the site U1369 sediments showing (a) Fe-rich smectite (15.52 mbsf), wavy structures with diffused Bragg's reflections $(\mathrm{d} 001=1.2 \mathrm{~nm})$, and elemental compositions $(\mathrm{Al} / \mathrm{Si}=0.48, \mathrm{Fe} / \mathrm{Si}=0.22)$; (b) $1 M$ illite $(15.52 \mathrm{mbs})$, discrete packets with distinct Bragg's reflections $(\mathrm{d} 001=1.0 \mathrm{~nm})$ and the repeated $1.0 \mathrm{~nm}$ spacings in $02 l$ reflections row; (c) $2 M_{1}$ illite (15.52 mbsf), distinct Bragg's reflections $(\mathrm{d} 001=1.0 \mathrm{~nm})$ with repetition of $2.0 \mathrm{~nm}$ spacings in $02 l$ reflections rows; and $(\mathrm{d})$ $3 T$ illite $(15.52 \mathrm{mbsf})$, distinct Bragg's reflections $(\mathrm{d} 001=1.0 \mathrm{~nm})$ with repetition of $3.0 \mathrm{~nm}$ spacing in $02 l$ reflections rows. The corresponding elemental composition of illite (b, c, d) 
shows high $\mathrm{Al} / \mathrm{Si}$ and $\mathrm{K} / \mathrm{Si}$ contents $(\mathrm{Al} / \mathrm{Si}=0.65-0.73, \mathrm{~K} / \mathrm{Si}=0.07-0.12)$.

Fig. 7. Bright-field TEM micrographs of the clay fraction $(<1 \mu \mathrm{m})$ for sediment/basalt interface at the sites U1365 and U1369 showing (a) K bearing Fe-rich smectite (U1365, 70.16 mbsf) with $\mathrm{Al} / \mathrm{Si}=0.17, \mathrm{~K} / \mathrm{Si}=0.08$, and $\mathrm{Fe} / \mathrm{Si}=0.52$; and (b) $\mathrm{K}$ bearing Fe-rich smectite (U1369, $15.52 \mathrm{mbsf}$ ) with $\mathrm{Al} / \mathrm{Si}=0.36, \mathrm{~K} / \mathrm{Si}=0.06$, and $\mathrm{Fe} / \mathrm{Si}=0.32$.

Fig. 8. EELS spectra of $\mathrm{Fe} L_{2,3}$ for the K-bearing Fe-rich smectite (nontronite) at the basalt/sediment interface showing (a) distinct peaks separation at 708 and $721 \mathrm{eV}$, and (b) the plotted integral ratio of $\mathrm{Fe} L_{3} / L_{2}$ on the universal curve as a function of Ferric iron concentration and Fe $L_{3} / L_{2}$ (van Aken et al., 1998). 


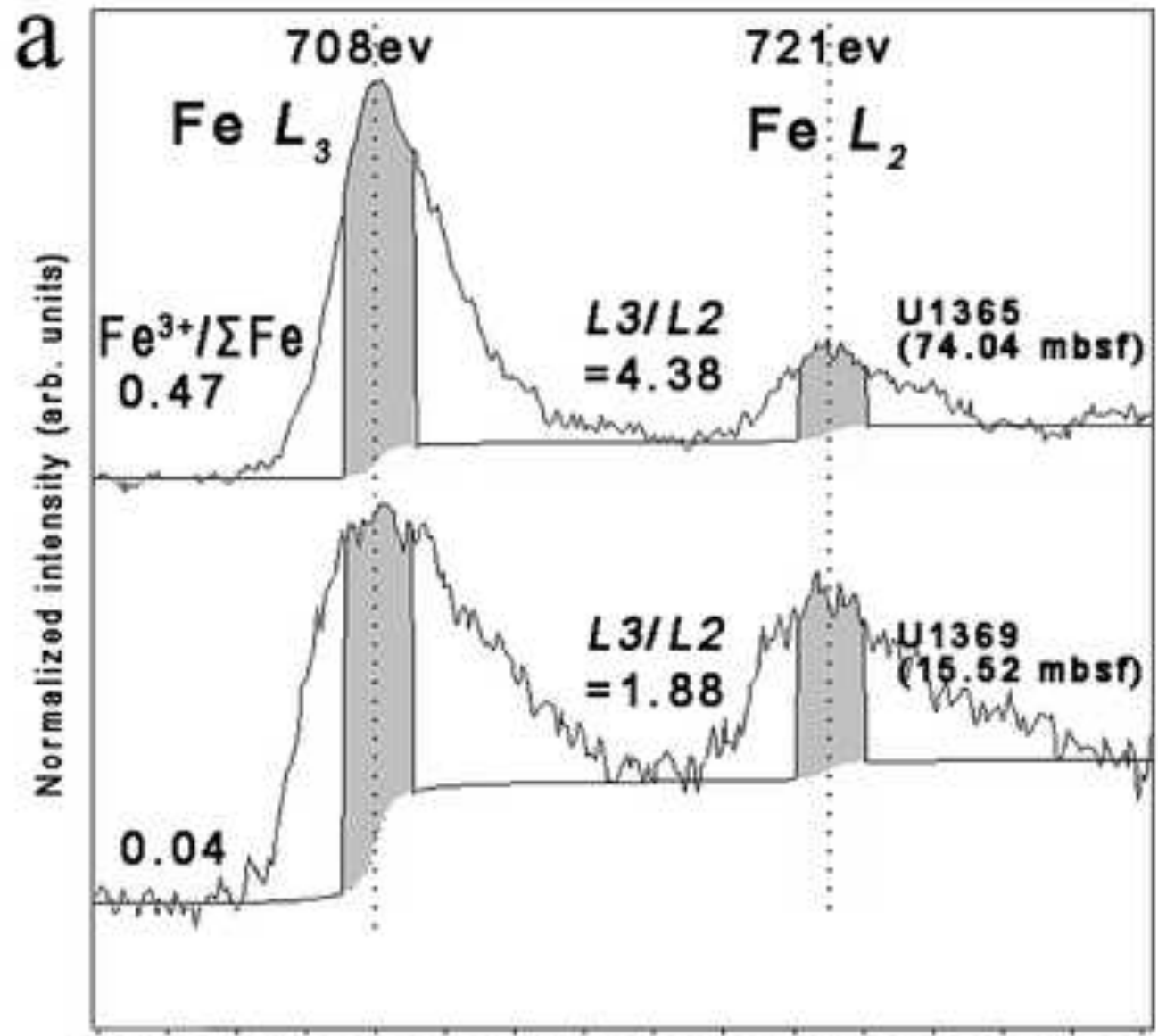

700702704706708710712714716718720722724726728730 eV

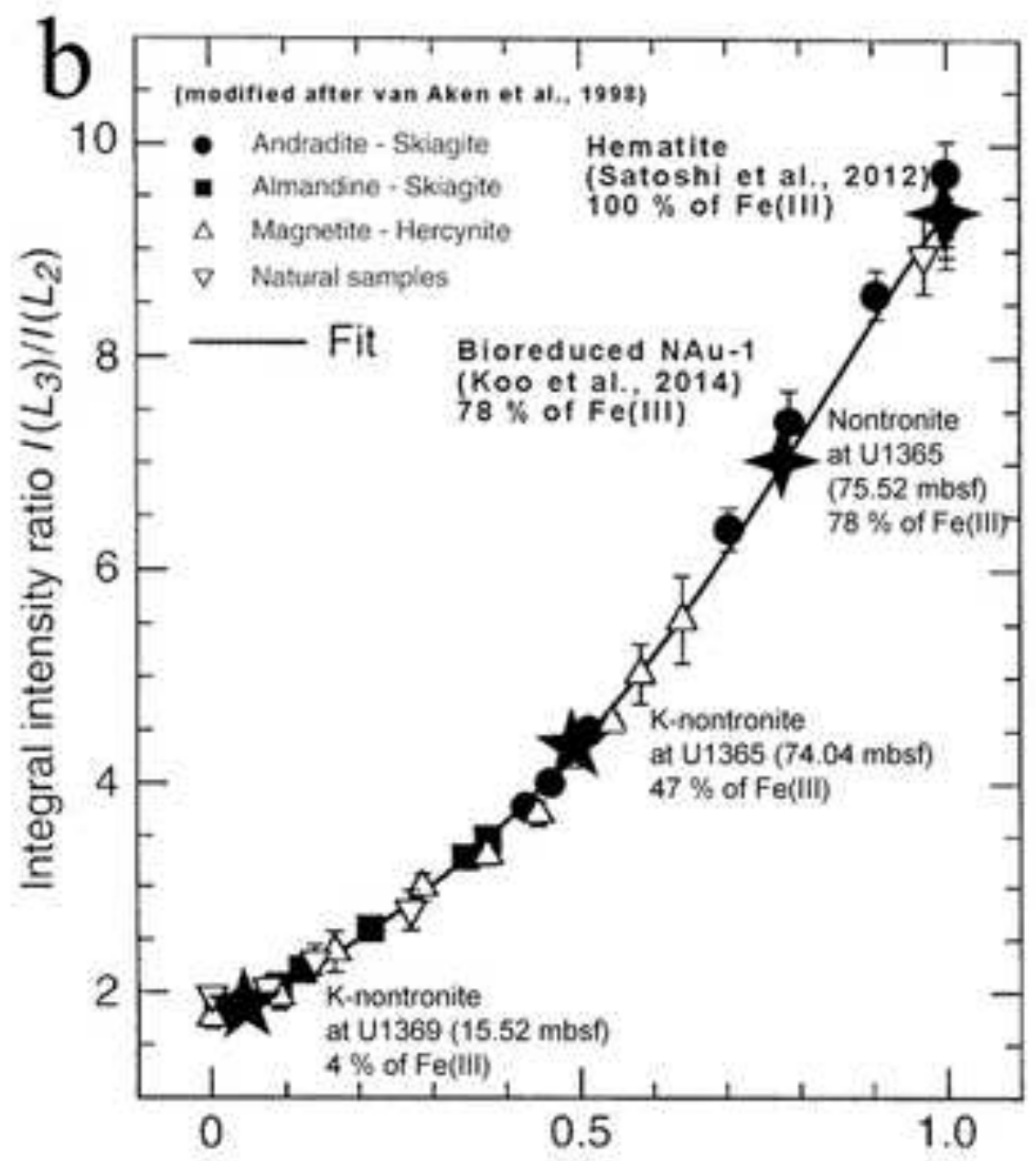

Ferric iron concentration $\mathrm{Fe}^{3+} / \Sigma \mathrm{Fe}$ 


\section{Table 1}

2 Summary of 7 drilling sites by IODP Exp. 329 in the SPG. The entire sediment column at

3 four sites and the upper $100 \mathrm{~m}$ of basaltic basement at three sites were cored. Each coring site

4 has various basement ages $(0-75 \mathrm{Ma})$ and water depths $(5075-5305 \mathrm{~m})$ depending on their

5 location within SPG.

\begin{tabular}{ccccccc}
\hline Sequence & Site & Lattitude & Longitude & $\begin{array}{c}\text { Water } \\
\text { Depth } \\
\text { (mbsl) }\end{array}$ & $\begin{array}{c}\text { Total } \\
\text { Sediment } \\
\text { Thickness } \\
(\mathrm{m})\end{array}$ & $\begin{array}{c}\text { Basement } \\
\text { Age } \\
\text { (Ma) } \\
\text { (Gradstein et } \\
\text { al., 2004) }\end{array}$ \\
\hline & $\mathrm{U} 1365$ & $-23^{\circ} 51^{\prime}$ & $-165^{\circ} 39^{\prime}$ & 5695 & 75 & $84-120$ \\
1 & $\mathrm{U} 1366$ & $-26^{\circ} 03^{\prime}$ & $-156^{\circ} 54^{\prime}$ & 5127 & 30 & $84-120$ \\
& $\mathrm{U} 1367$ & $-26^{\circ} 29^{\prime}$ & $-137^{\circ} 56^{\prime}$ & 4289 & 27 & 33.5 \\
\hline & $\mathrm{U} 1368$ & $-27^{\circ} 55^{\prime}$ & $-123^{\circ} 10^{\prime}$ & 3740 & 16 & 13.5 \\
\hline & $\mathrm{U} 1369$ & $-39^{\circ} 19^{\prime}$ & $-139^{\circ} 48^{\prime}$ & 5277 & 16 & 58 \\
& $\mathrm{U} 1370$ & $-41^{\circ} 51^{\prime}$ & $-153^{\circ} 06^{\prime}$ & 5075 & 68 & $73.6-79.5$ \\
& $\mathrm{U} 1371$ & $-45^{\circ} 58^{\prime}$ & $-163^{\circ} 11^{\prime}$ & 5305 & 131 & $71.5-72.9$ \\
\hline
\end{tabular}

6 

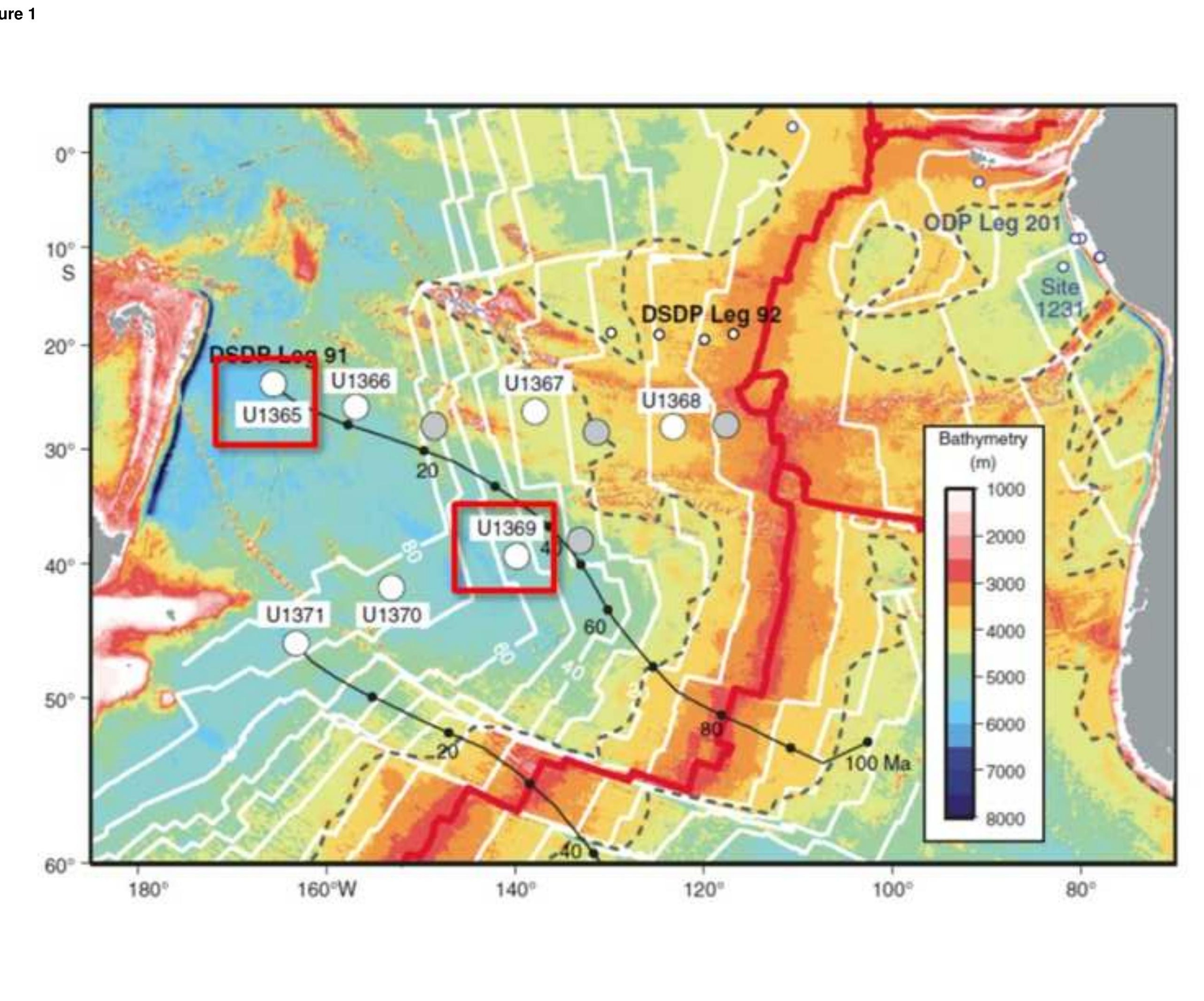

.

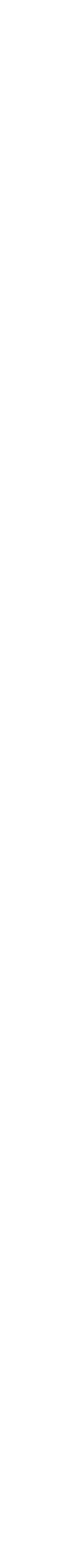

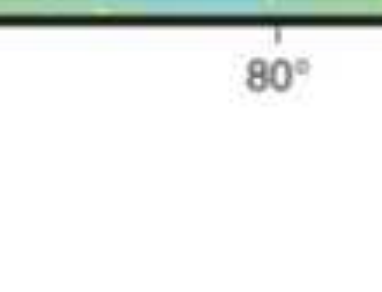


Figure2
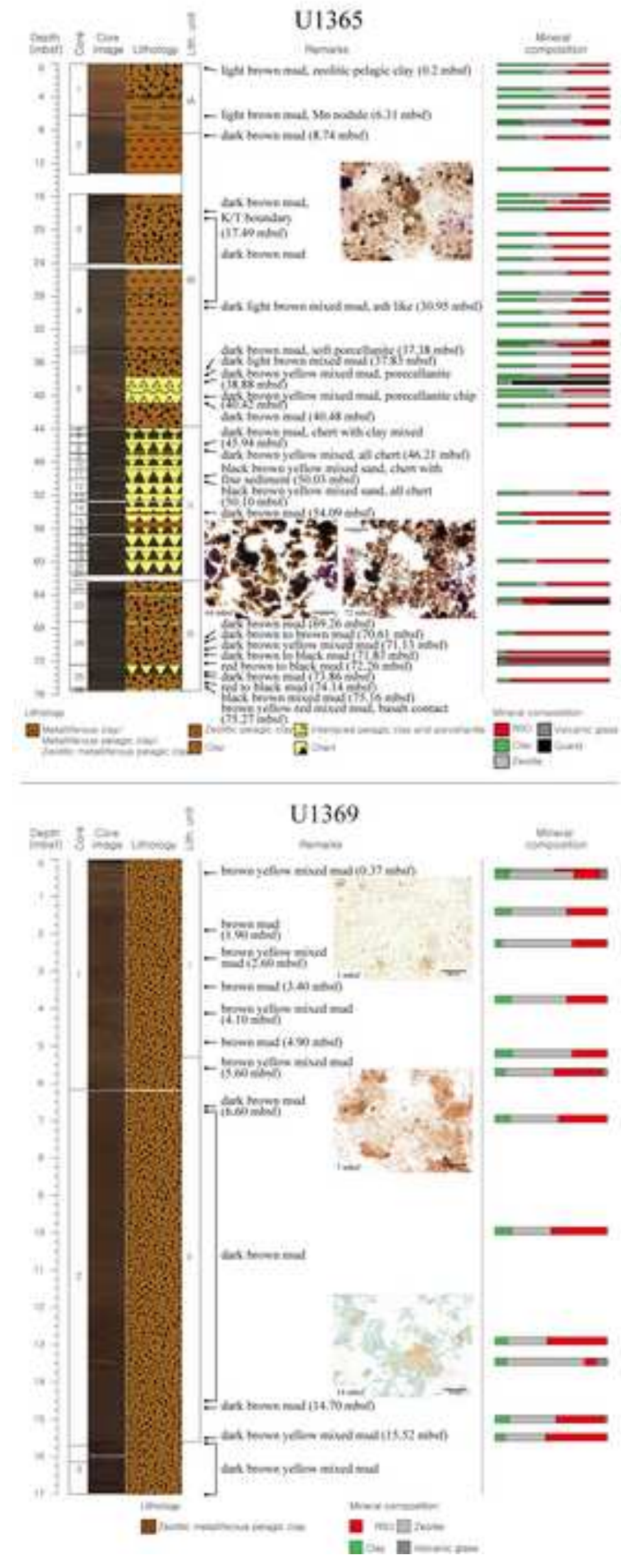

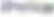

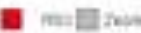

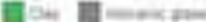

vines: 
Figure 3

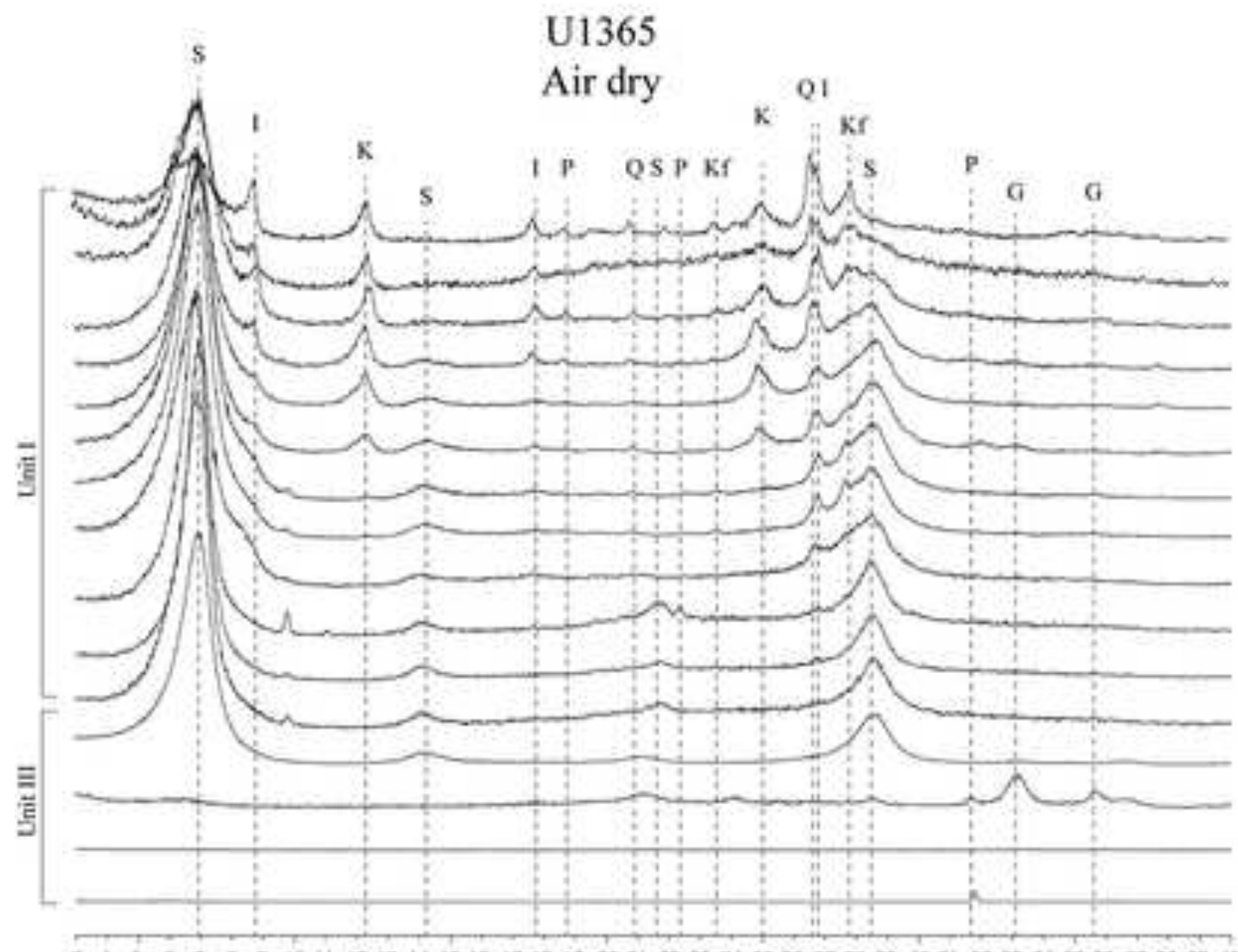

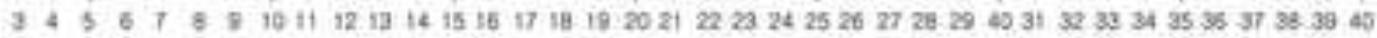

Degree $2 \theta$

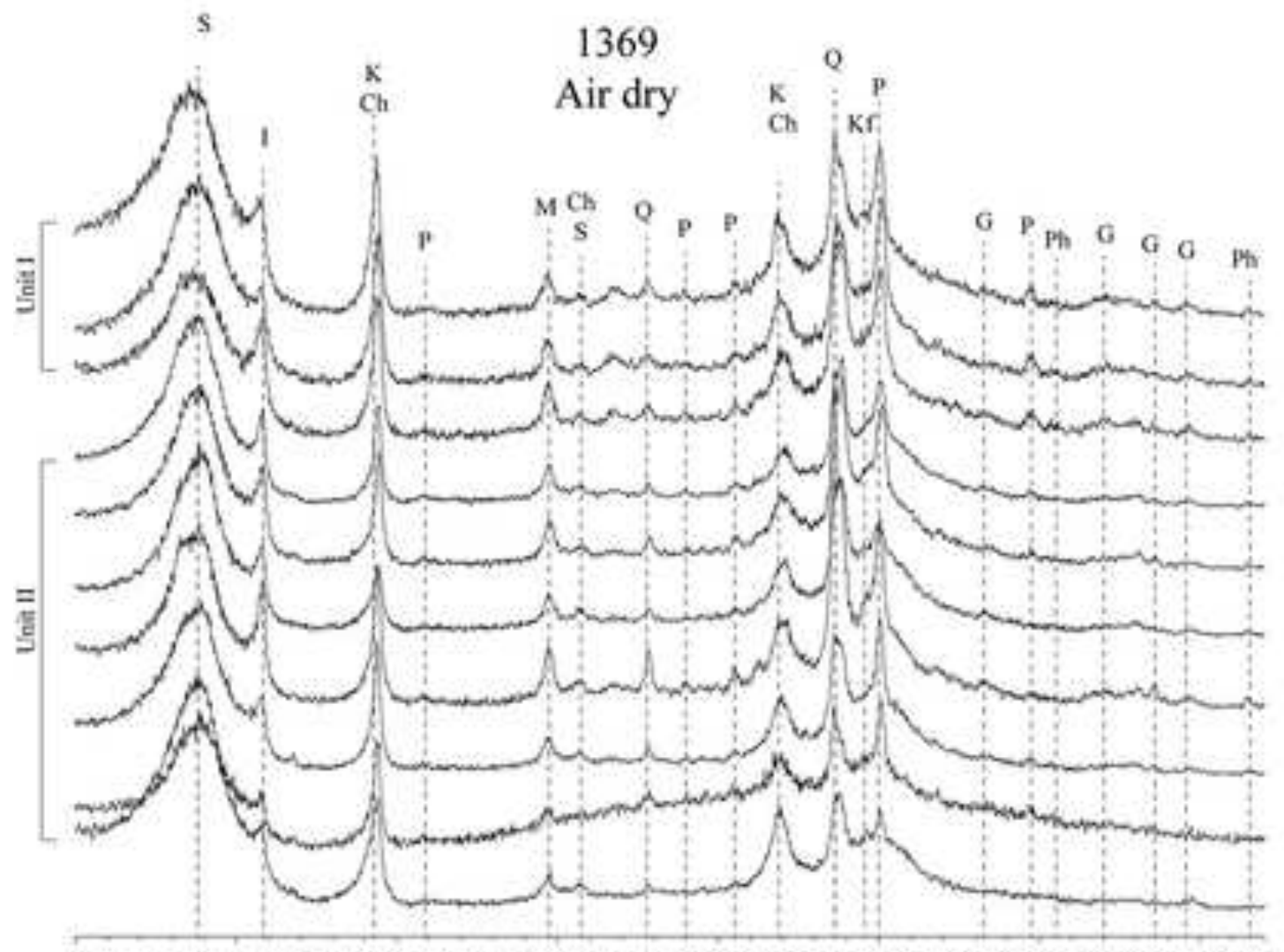

Glycolation

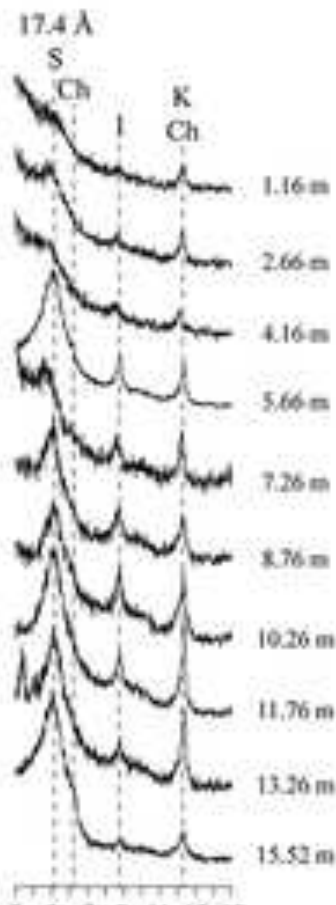

Degree $2 \theta$ 


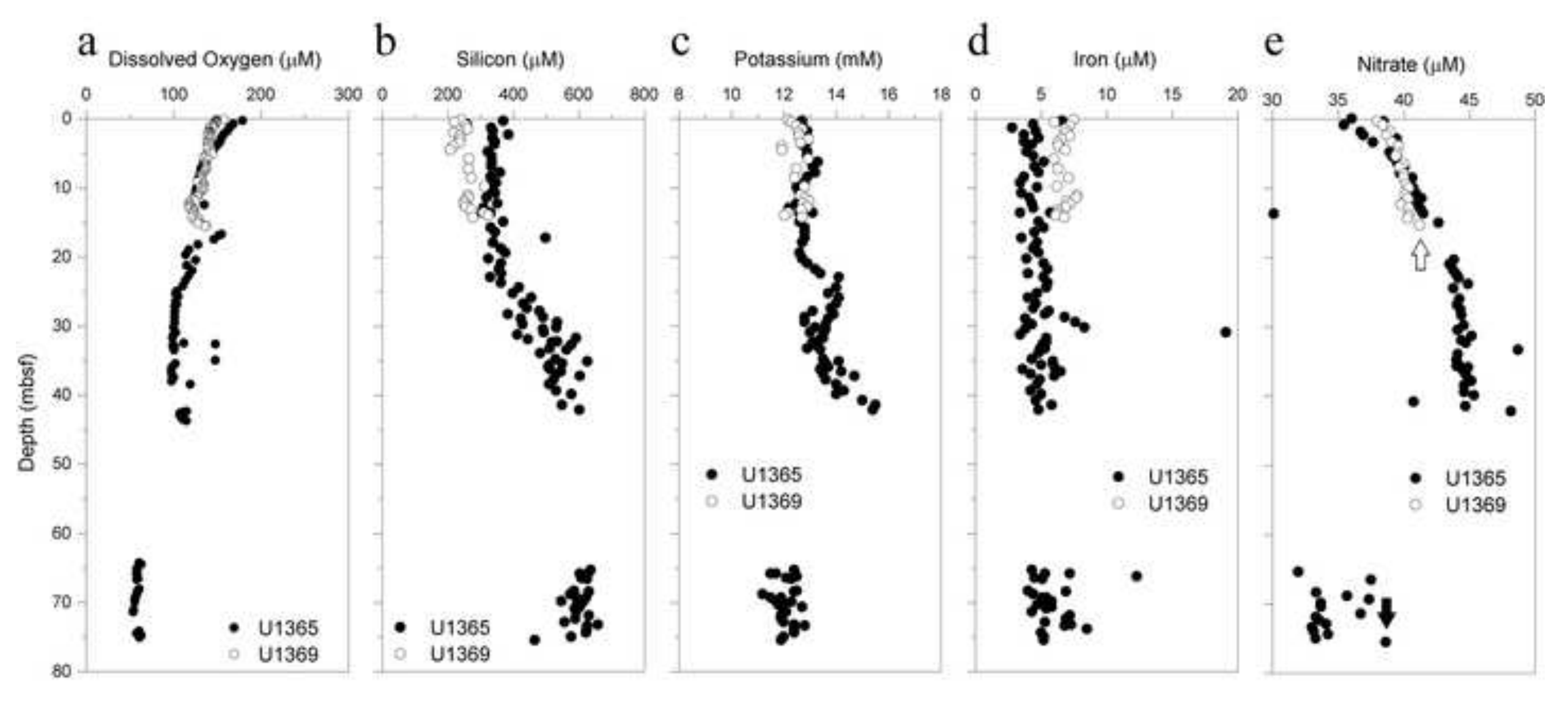



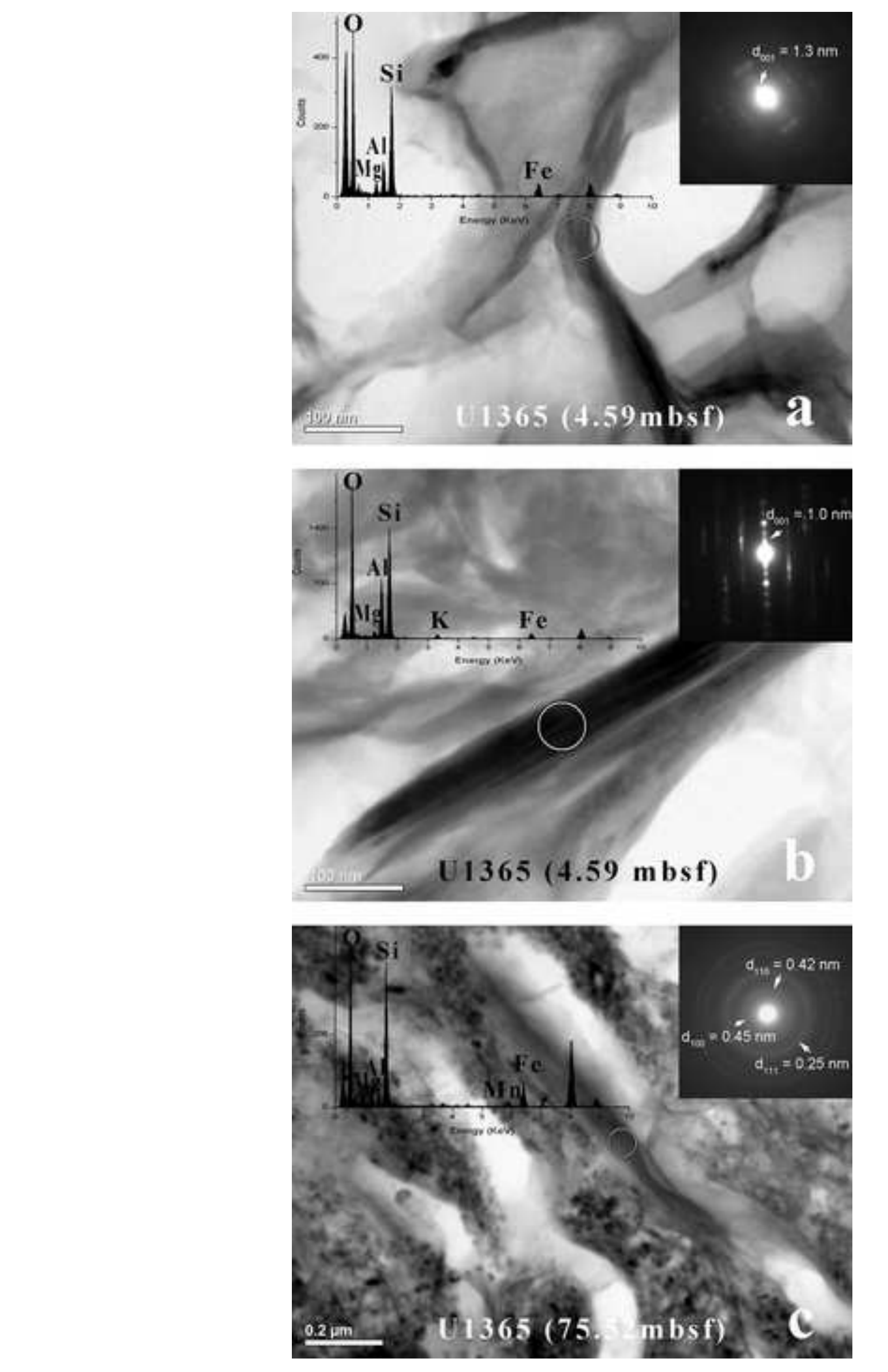

Figure 5

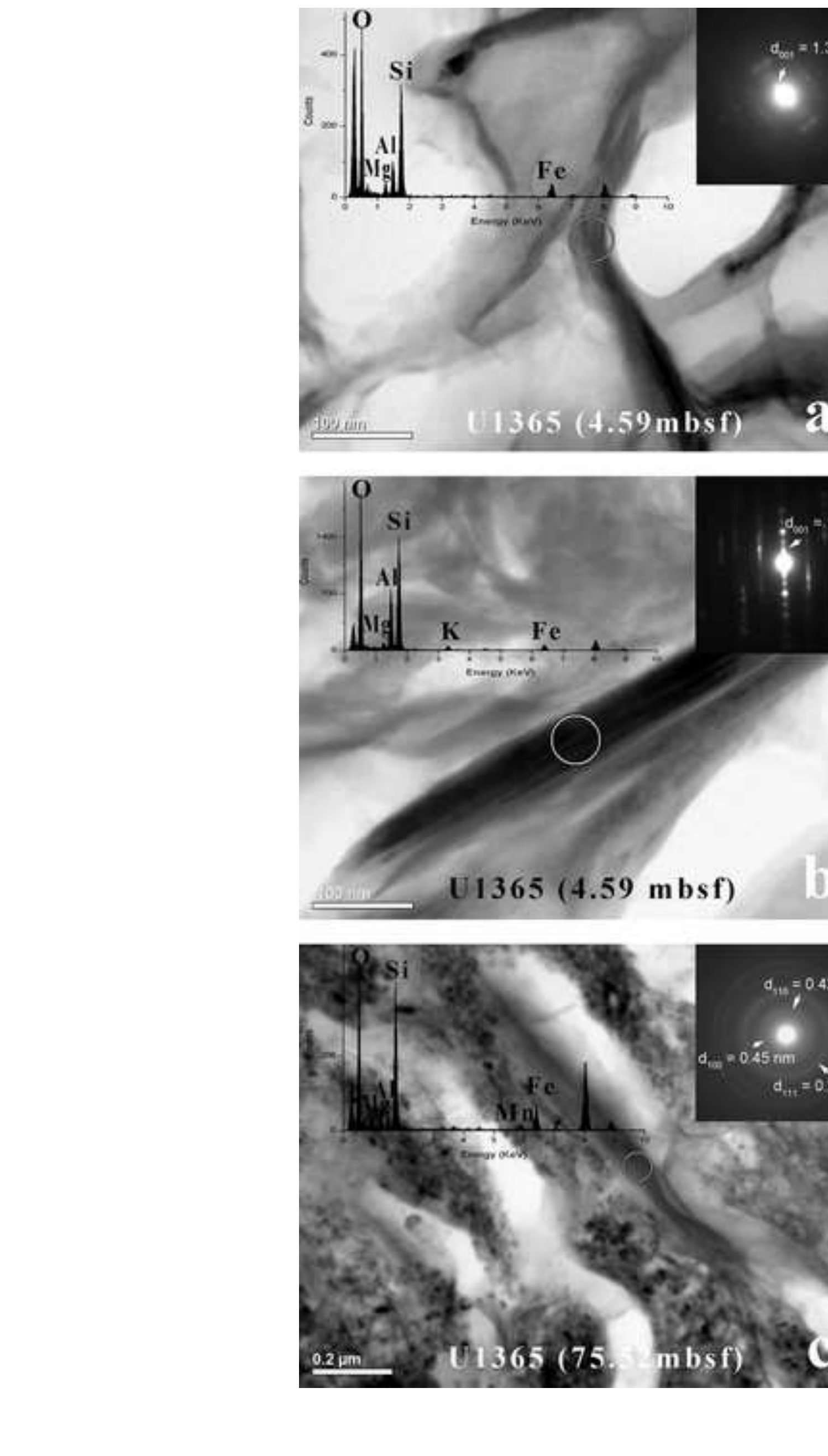

$$
\text { 政 }
$$

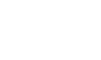

.

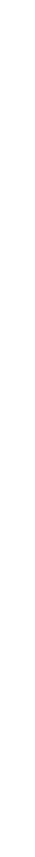



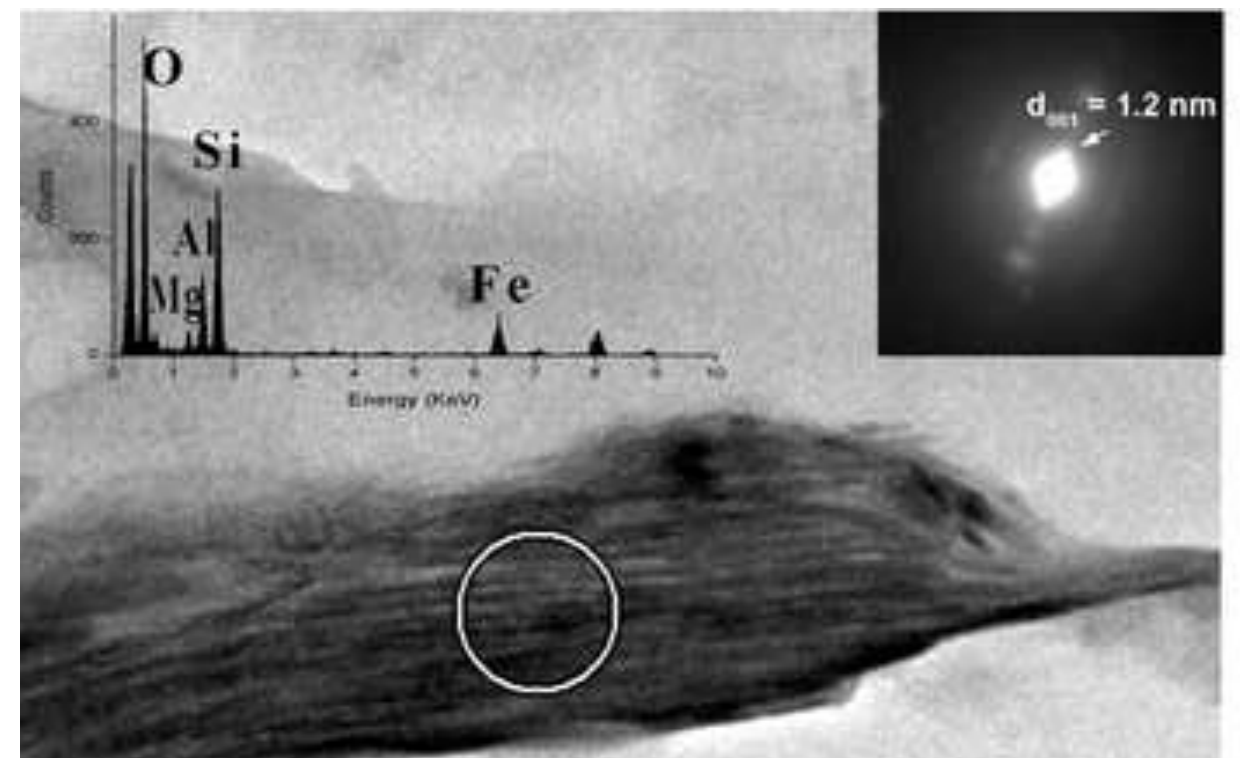

U1369 (15.52 m bsf)

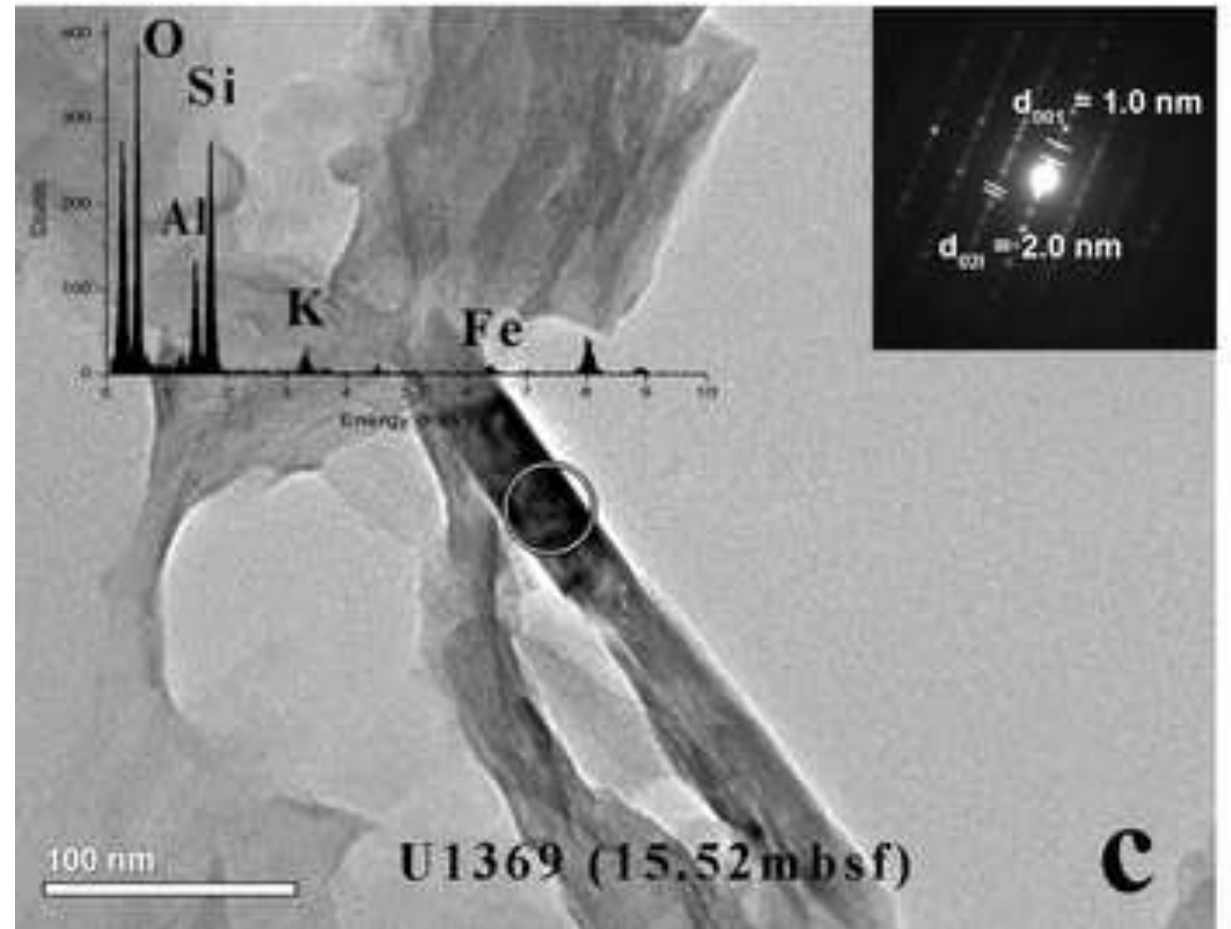

a
U1369 (15.52 mbsf)
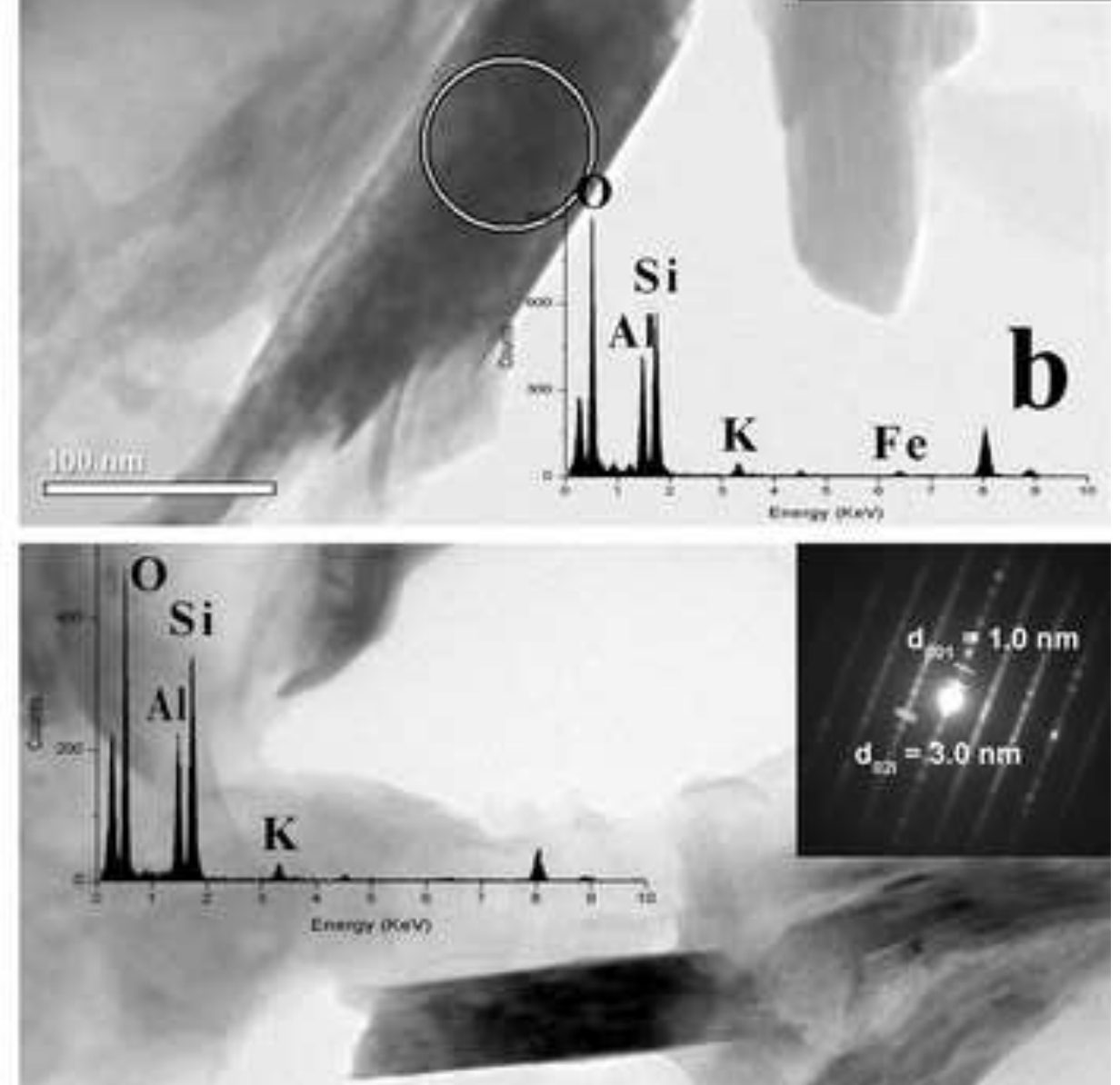

$100 \mathrm{~nm}$

U1369 (15.52 mbsf)

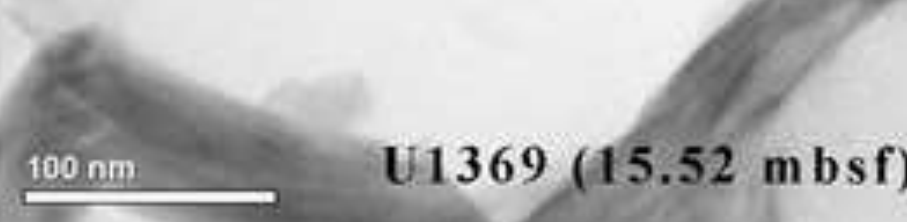




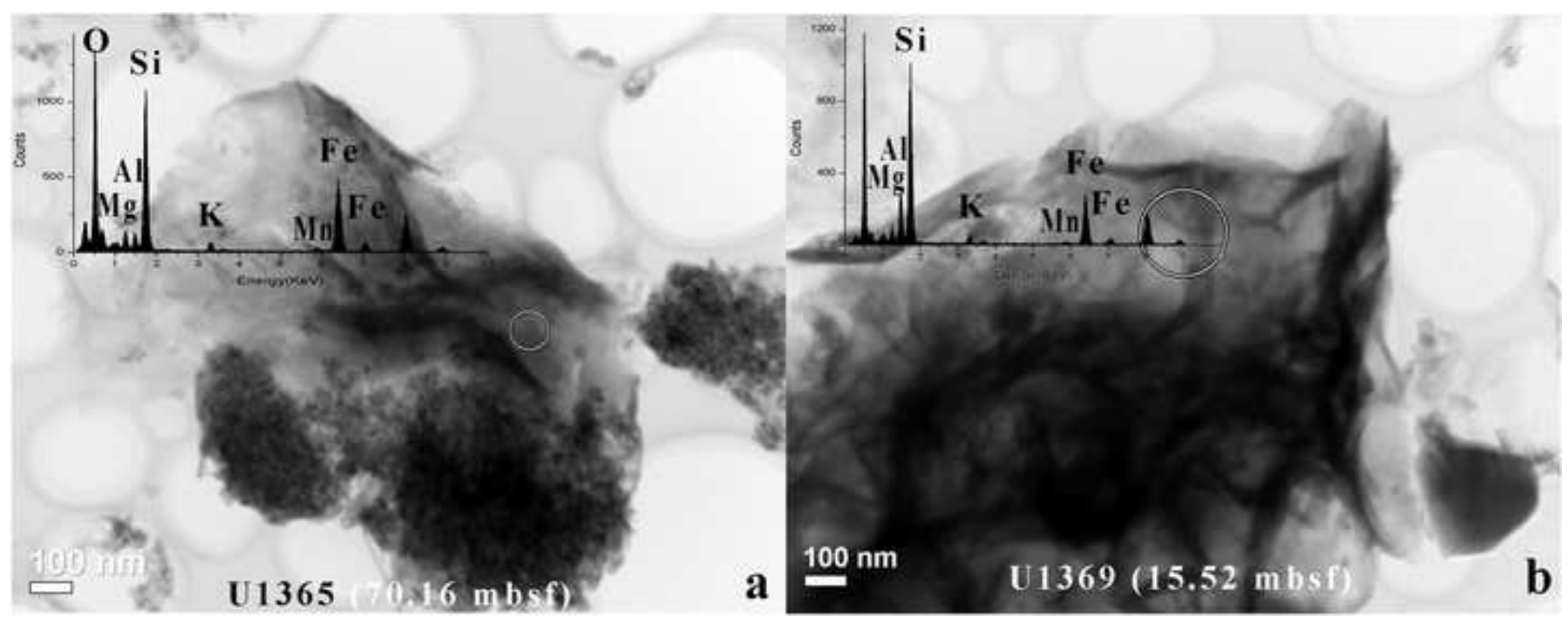

b



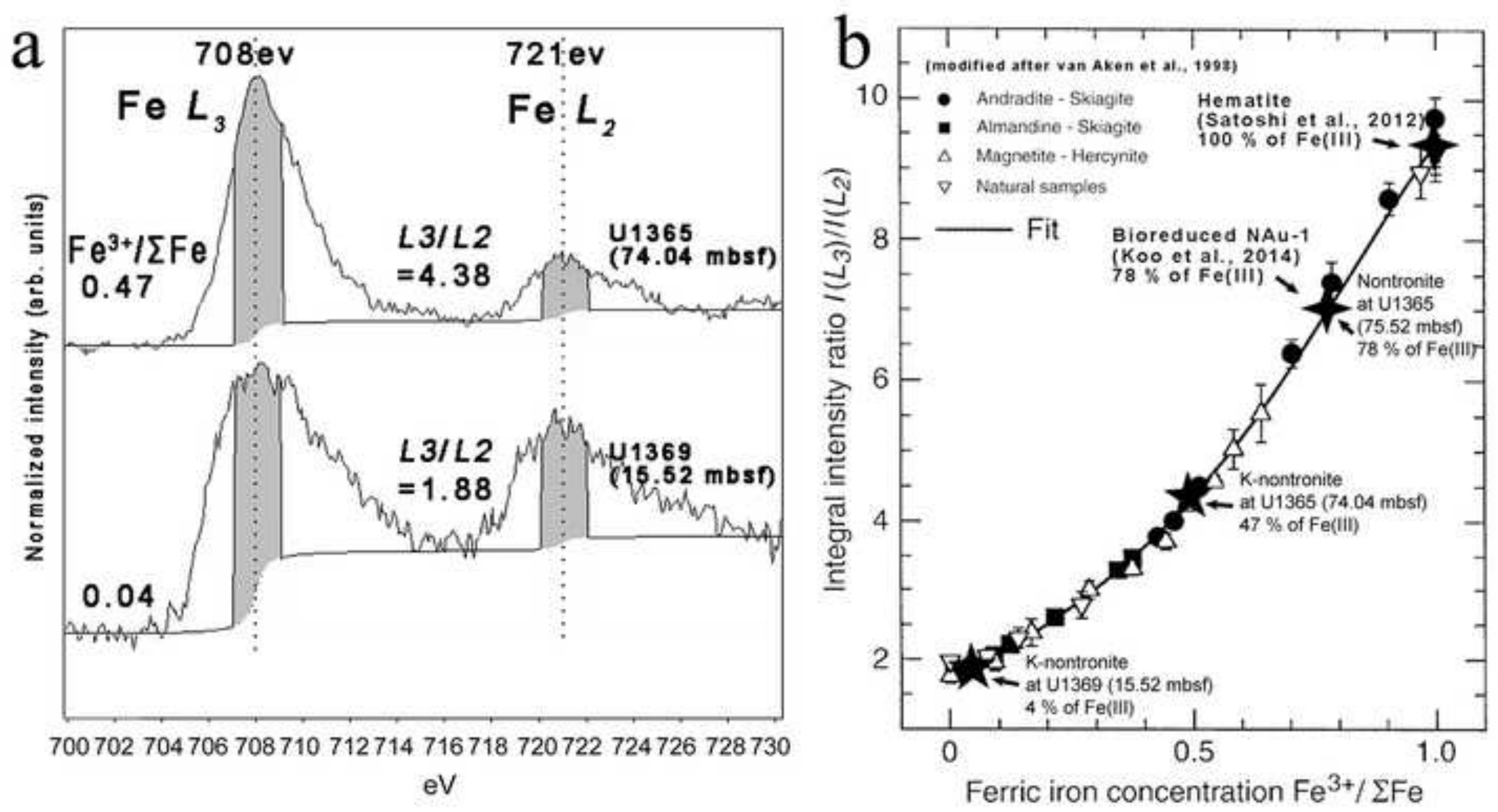


\section{Abstract}

Subseafloor sediment and basalt rock samples at seven sites in the South Pacific Gyre (SPG) were recovered by Integrated Ocean Drilling Program Expedition 329 (2010.10.8 2010.12.13). Microscopic and spectroscopic measurements on the structural Fe-redox states and the elemental composition of smectite, and polytypes of illite in the sediment at two sites (U1365 and U1369) were performed to understand the origin/formation mechanism of clay minerals in the oligotrophic open ocean. The dominant phases of clay minerals found in the present study were smectite and illite polytypes. Suggestive of non-uniform early diagenetic processes in the expansive SPG seafloor, higher ordering of illite polytypes $\left(1 M, 2 M_{l}\right.$, and $\left.3 T\right)$ were identified at site U1369 while disordered $1 M_{d}$ illite were found at U1365. Smectites of hydrothermal origin (Al-rich beidellite, and saponite) were observed at U1369. Fe-rich montmorillonite minerals that are likely associated with the terrigenous input, were dominant at U1365. Nontronite (Fe-rich smectite) was detected at both sites. Red-brown to yellowbrown semiopaque oxide minerals (RSO) were widely distributed with Fe-rich smectite near the basaltic crust at U1365. Lower observed heat flow at U1365 relative to U1369 provides a possible explanation for the observed variability in clay mineral speciation between these two sites. The presence of K-nontronite at the basalt/sediment interface at both sites indicates an oxidative basalt alteration; however variations in the oxidation states of structural $\mathrm{Fe}$ in nontronite measured by EELS indicate that reductive environment persists locally at the basalt/sediment interface.

Keywords: South Pacific Gyre; K-nontronite; diagenesis; Illite polytypism; IODP Expedition 
